\title{
WestVirginiaUniversity
}

THE RESEARCH REPOSITORY @ WVU

West Virginia Agricultural and Forestry Experiment

Davis College of Agriculture, Natural Resources

Station Bulletins

And Design

$1-1-1970$

\section{Effect of an advertising campaign on hot cocoa consumption}

James H. Clarke

Follow this and additional works at: https://researchrepository.wvu.edu/ wv_agricultural_and_forestry_experiment_station_bulletins

\section{Digital Commons Citation}

Clarke, James H., "Effect of an advertising campaign on hot cocoa consumption" (1970). West Virginia Agricultural and Forestry Experiment Station Bulletins. 592T.

https://researchrepository.wvu.edu/wv_agricultural_and_forestry_experiment_station_bulletins/696 @ WVU. It has been accepted for inclusion in West Virginia Agricultural and Forestry Experiment Station Bulletins by an authorized administrator of The Research Repository@WVU. For more information, please contact ian.harmon@mail.wvu.edu. 

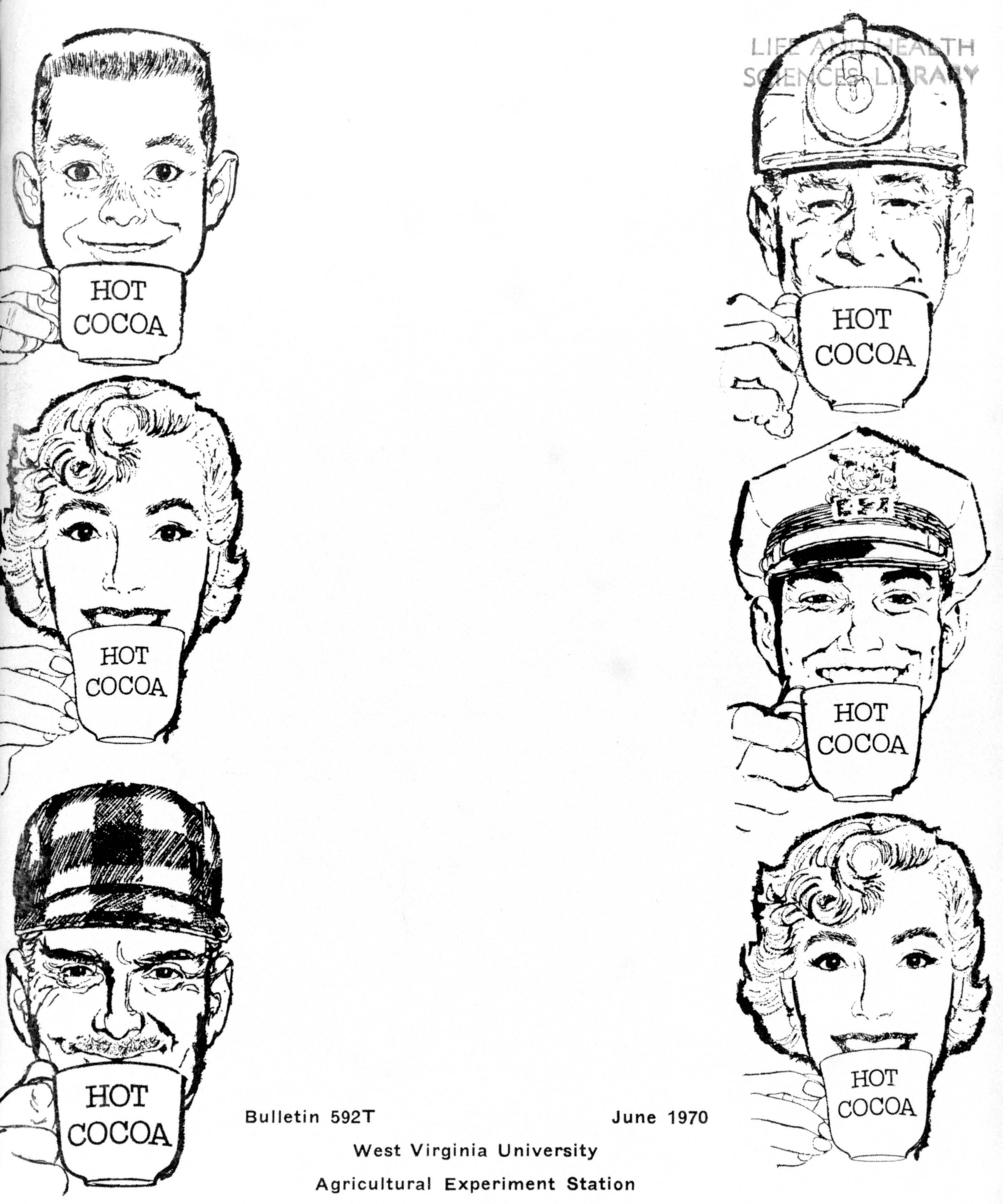

\section{Effect of an Advertising Campaign on Hot Cocoa Consumption}




\section{SUMMARY AND CONCLUSIONS}

The major objective of this research was to study the impact of a 12-week advertising campaign on consumer behavior, using test and control cities and sample surveys before, during, and after the campaign.

It was hypothesized that an advertising campaign for hot cocoa would create among consumers an awareness of the campaign and its themes. Awareness would then lead to a favorable attitude change toward hot cocoa which would result in increased use of hot cocoa by consumers. It was expected that the consumer use of hot cocoa would be affected by socio-economic factors, as well as awareness of advertising, and attitudes concerning competing products and their use.

The research plan included personal interviews with a random cluster sample of respondents. Interviews were conducted before and after the advertising campaign in the test city and in a control city. Also, at the end of the four-week intensive phase of the campaign, telephone interviews were conducted in the test city. Results are based on 5,206 interviews.

Awareness of hot cocoa advertising and the advertising themes was quite low. Housewives indicated increased awareness of new recipes for hot cocoa, but the stimulus provided by the advertising did not result in a significant increase in housewife use of the recommended recipe.

Increased advertising exposure, more frequently applied in the intensive phase of the campaign, resulted in increased consumer recognition of the advertising themes. However, the effect of this relatively intensive advertising appeared to have a short life. Any carry-over effect had disappeared within two months following the intensive campaign, even though the effect was supplemented by diminished advertising exposure. The hypothesis that consumers would be aware of advertising and advertising themes is accepted.

The attitudes and beliefs about hot cocoa as a breakfast beverage were changed only slightly by the advertising campaign. The changes were favorable to increased hot cocoa consumption in some instances but were unfavorable in others. The hypothesis that adult consumers' attitudes toward hot cocoa can be changed favorably toward the product was not conclusively supported.

Hot cocoa was consumed by a smaller proportion of respondents than most other meal-time beverages. The intensive phase 
of the campaign resulted in a significant increase in the proportion of respondents who drank hot cocoa on the day interviewed, but the proportion was still quite low (5.4 per cent). Frequency of consumption increased during the intensive phase of the campaign, and the estimated volume of hot cocoa consumption increased about one-third.

The hypothesis that an intensive advertising campaign will increase the use of hot cocoa was supported. However, at the end of the entire campaign, there was a decline in the proportion of respondents who drank hot cocoa on the day interviewed and no change in the proportion who sometimes drank hot cocoa for breakfast. Frequency of consumption also was lower. The hypothesis that an advertising campaign of the type tested, including its low-intensity phase, will increase the use of hot cocoa by adults is rejected.

The findings do not completely support the sequence of events indicated in the model specified. Intensive advertising, however, did appear to follow the sequence of the model and was estimated to result in increased revenue for the farmers who sponsored it.

Because of the costs of this campaign, of the low incidence of hot cocoa consumption, of the campaign's small effect on milk sales, and of the limited and diverging effect of the advertising on consumers' image of hot cocoa, it appears that the dairy farmers would be well advised to seek alternative uses for resources allocated to advertising and promotion in campaigns of the type tested.

\section{THE AUTHOR}

James H. Clarke is Agricultural Economist 


\section{CONTENTS}

PART I, INTRODUCTION

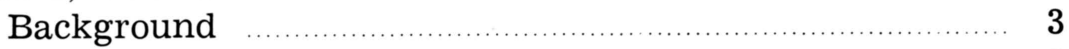

The Problem …........................................................... 3

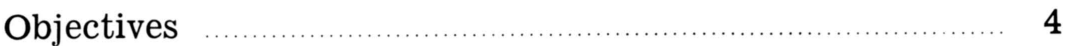

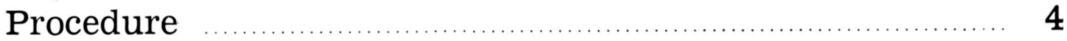

PART II, EFFECT OF ADVERTISING ON DEMAND …..... 5

Introduction

Theory of Consumer Behavior …............................. 6

Effect of Advertising on Consumer Response …............ 10

Empirical Studies …............................................ 11

PART III, FRAMEWORK AND APPROACH OF THE STUDY .. 15

Theoretical Framework …........................................ 15

Empirical Approach Used …......................................... 20

PART IV, CONSUMER AWARENESS OF ADVERTISING AND CONSUMER ATTITUDES TOWARD HOT COCOA ….... 26

Hypotheses Tested ................................................ 28

Respondents' Awareness of Hot Cocoa Advertising or Promotion

Obstacles to Awareness ................................................. 34

Summary of Changes in Consumer Awareness, Attitudes, and Recipe Use

PART V, APPRAISAL OF IMPACT OF ADVERTISING ON CONSUMER BEVERAGE HABITS AND MILK SALES

Hypotheses Tested

Hot Cocoa Consumption Habits ..................................... 40

Frequency of Consumption of Hot Cocoa ....................... 44

Relationship of Socio-Economic Factors to

Hot Cocoa Consumption .......................................... 47

Milk Sales in Market During Campaign ........................ 48

Milk Consumption Habits ........................................... $5 \mathbf{5 2}$

Summary of Impact of Advertising on Behavior ............ 56

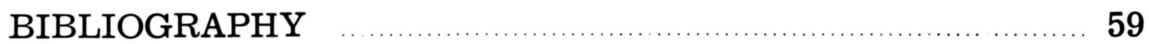

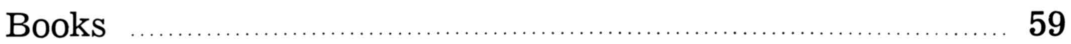

Publications of Agencies and Associations …..............6 60

Periodicals

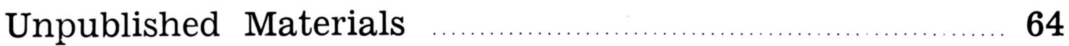

ACKNOWLEDGMENTS …......................... Inside Back Cover 


\title{
Effect of an Advertising Campaign on Hot Cocoa Consumption
}

\author{
JAMES H. CLARKE
}

\author{
PART I \\ INTRODUCTION
}

\section{Background}

Advertising, merchandising, and other programs designed to increase the demand for products and services of agriculture and other industries in the United States now involve large sums of money and much human effort. Frye and Grubbs reported that of the $\$ 10$ billion which is estimated to be spent annually on advertising, some 17 to 20 per cent is believed to be spent on advertising of food and food products. ${ }^{1}$ They further reported that during 1958 agricultural groups were estimated to have spent $\$ 66.6$ million on promotional activities. Dairy groups were estimated to have spent approximately $\$ 25$ million on promotional activities, of which $\$ 13.8$ million was for advertising. ${ }^{2}$ During 1962, agricultural groups spent about $\$ 86$ million on United States programs to promote agricultural products. ${ }^{3}$ Producers furnished 74 per cent of the promotional funds reported.

\section{The Problem}

Dairy farmers have frequently questioned whether the promotional programs they sponsor actually increase dairy product sales or otherwise influence consumers. Producers in fluid milk markets are concerned particularly with the results obtained from advertising milk since they are proportionally the largest contributors to these advertising programs.

Previous studies made for the American Dairy Association had shown that milk consumption by adults at breakfast was lower than at other times of the day. ${ }^{4,5}$ It is also well known that

1Frye, Robert E. and Violet Davis Grubbs, Promotion of Farm Produets by Agricultural Groups, United States Department of Agriculture, Marketing Research Report No. 380, (Washington: Government Printing Office, January, 1960), p. 4 .

${ }^{2}$ Tbid., p. 20. tural Groups, United States Department of Agriculture, Marketing Research Report No. 742, (Washington: Government Printing Office, December, 1965), p. v.

${ }^{4}$ American Dairy Association, Public Attitudes and Uses of Dairy Produets, Highlights Study No. 3, (Chicago: American Dairy Association, Fall, 1954), p. 27, Table 2 .

${ }^{5}$ American Dairy Association, Public Attitudes and Uses of Dairy Produets, Highlights Study No. 8, (Chicago: American Dairy Association, Fall, 1958), p. 17, Table 4 . 
consumption of most products, especially food products and beverages, is influenced by many variables which are impossible to control and difficult to measure. The limited funds available for both advertising and research dictated that examination be made of only a few of the factors pertaining to the relationship of advertising to milk consumption.

\section{Objectives}

The primary objective of this study was to measure as precisely as possible the effect of advertising on consumer behavior toward milk and the attitudes of consumers concerning the product.

Secondary objectives included determining consumer awareness of advertising themes and changes in consumer attitudes and beliefs relative to hot cocoa. Changes in consumer consumption were to be examined. Knowledge and use of hot cocoa recipes by housewives was also sought.

It was expected that certain characteristics of consumers, such as age, sex, number of children, education, and income, would be related to the changes observed.

\section{Procedure}

The study was limited to plans for analyzing the effects of an advertising program for hot cocoa made with milk as a breakfast beverage which an advertising sponsor and its advertising agency would consider adequate to increase hot cocoa use and thereby increase milk sales. The original proposal was to study the effects of several levels of advertising expenditures in order to discover the level of contributions producers might profitably expend on advertising. This proposal had to be dropped because of budgetary constraints on both the sponsor and the Agricultural Experiment Station.

The advertising campaign was sponsored by the Dairymen's Cooperative Sales Association and the American Dairy Association. Hot cocoa was selected for the advertising campaign because the sponsors' advertising agency believed it would be a better substitute for coffee and tea than milk as a breakfast drink for adults and that it also would be easier to increase the consumption of hot cocoa during the winter period through advertising than during other periods of the year.

The sponsors chose a three-month campaign for hot cocoa during the winter. It was also believed that longer periods of ad- 
vertising would provide the opportunity for additional exogenous variables to influence consumption of the test product. In this study, it was recognized that both the price and income inelasticity of the demand for milk are low and that long periods of advertising would be required to change consumers' behavior and attitudes toward milk. Thus, a three-month period of study was accepted as one which would limit changes in relationships among the major variables that influence or are associated with hot cocoa consumption, but at the same time provide a period of exposure to advertising long enough to be reflected in consumers' behavior and attitudes toward hot cocoa. There was also a necessity for holding the effects of selected variables constant while examining the effect of a specified variable on consumer behavior or attitudes toward a product. The three-month period held promise as one for which statistical analyses would provide the necessary control.

It was decided that the principal device for measuring effects of the advertising program would be personal interviews conducted before and after the advertising campaign. An interview questionnaire was developed in cooperation with the research personnel of the American Dairy Association and with the sponsors' advertising agency, Ketchum, MacLeod, and Grove, Inc. This also involved pre-testing the questionnaire as originally formulated and developing a questionnaire for telephone interviews.

Test and control cities were selected in consultation with the sponsors and their advertising agency. Following this, sampling methods and population samples were developed.

The analyses will be presented in the parts which follow.

\section{PART II}

\section{EFFECT OF ADVERTISING ON DEMAND}

\section{Introduction}

Over time, the analyses of changes in demand for goods and services have intrigued and occupied anthropologists, advertising executives, home economists, marketing theorists, psychologists, social psychologists, sociologists, and practitioners of other disciplines. Businessmen have sought the guidance of specialists trained in these disciplines to enlarge the markets for their products. Scientists and specialists in all these disciplines have made contributions to the analyses of market changes and these contributions have increased the understanding of the factors af- 
fecting observed human behavior as it is related to the demand for food products. Despite much information about size of markets, incomes of consumers, and the demographic characteristics of consumers, Britt reported in 1950 that little was known concerning why people are motivated to buy. ${ }^{1}$

\section{Theory of Consumer Behavior}

A complete review of all studies of factors influencing consumer behavior is outside the scope of this study, but an attempt will be made to relate specific theories which explain changes in the demand for food products. Attention was given to those theories which explain the demand for milk since milk is usually the principal and most costly ingredient in hot cocoa.

In attempting to analyze consumer purchase behavior, marketing specialists have, in large part, depended on theories developed in other social science disciplines.

ECONOMIC CONSIDERATIONS. Stigler indicates that four fundamental factors determine the quantity of each commodity purchased by any consumer: (1) the price of the commodity which is being purchased; (2) the income of the consumer; (3) the prices of substitute commodities; and (4) the consumer's tastes and preferences. ${ }^{2}$ Of these factors, the most difficult to measure or quantify is consumer tastes and preferences. Economists have frequently simplified their analyses by assuming that tastes and preferences do not change. 'They recognize, however, that this assumption is seldom the case. Nevertheless, few professional economists have studied advertising. ${ }^{3}$ Other disciplines, as will be pointed out later, have attempted to measure how and why these tastes and preferences change.

Food products, as a group, are generally known to have relatively inelastic price and income coefficients. Studies reported by Brandow have shown that the quantities of both milk and other beverages, frequently drunk with meals, are inelastic with regard to both price and income." Inelasticity describes a situation in which relative changes in quantities taken by consumers are

${ }^{1}$ Britt, Steuart Henderson, “The Strategy of Consumer Motivation," Journal of Marketing, Vol. 14, No. 2, (April, 1950), pp. 666-674.

'Stigler, George J., The Theory of Price, (New York: The MacMillan Company, $1946)$, pp. $86-90$.

"'Will the Dismal Science Study the Happy Art?" (Editorial), Journal of Advertising Research, Vol. 7, No. 2, (June 1967), pp. 58-59.

${ }^{4}$ Brandow, G. E., Interrelationships Among Demands for Farm Produets and Implieations for Control of Market Supply, Pennsylvania Agricultural Experiment Station. Bulletin No. 680; (University Park, Pennsylvania: August, 1961), pp. 17,37 , and 41 . 
less than the associated relative changes in prices of the product or incomes of the consumers. Brandow estimated that fluid milk and cream had a price elasticity of -0.285 and an income elasticity of $0.16 .^{5}$ The beverage group, consisting mostly of coffee but including tea and cocoa, was estimated to have a price elasticity of -0.35 and an income elasticity of 0.23 . $^{6}$ Thus, it can be expected that changing the tastes and preferences of consumers for hot cocoa would not be an easy undertaking.

PSYCHOLOGICAL CONSIDERATIONS. Bayton indicates that he has been made uncomfortable by economists' seemingly great reliance upon price as a critical product attribute in consumer demand. He points out that his:

uneasiness always increases upon completion of a consumer research project which shows very little evidence of price being discriminated out of a total configuration of product attributes into a psychologically controlling position. ${ }^{7}$

Motivation is considered basic to consumer behavior and is related to biogenic and psychogenic needs or drives. Pitfalls in the analysis of motivation include the assumption that a particular situation involves only one specific need, and that identical behavioral patterns have identical motivational backgrounds. ${ }^{8}$

Woods reported that factors underlying food consumption were motivational. ${ }^{9}$ He indicated that people eat because they are (1) hungry, (2) bored, (3) it is time to eat, or (4) to provide an outlet for some psychological force. Woods considers two processes which determine that a specific product will be bought or consumed. The first of these is the process of motivation (hunger) and the second, the satisfaction of the hunger need by the selection of particular foods or brands of food.

What a person eats at a particular time, however, is usually outside this kind of motivation. Hot cocoa, for example, may be drunk for breakfast because (1) it is always drunk for breakfast (habit); (2) the cocoa is available when breakfast is prepared (impulse); (3) cocoa is healthy (motivation); or (4) everyone else is drinking cocoa (social pressure).

5Ibid., pp. 17 and 37.

elbid., pp. 17 and 41 .

7Bayton, James A. "Contributions of Psychology to the Microeconomic Analysis of Consumer Demand for Food," Journal of Farm Eeonomies, Vol. 45, No. 5, (December, 1963), p. 1432 .

s, Bayton, James A., "Motivation, Cognition, Learning-Basic Factors in Consumer Behavior," Journal of Marketing, Vol. XXII, No. 3, (January, 1958), p. 282.

${ }^{9}$ Woods, Walter A., "Psychological Dimensions of Consumer Decision," Journal of Marketing, Vol.'24, No. 3, (January, 1960), pp. 15-19. 
It has been observed that the same level of income or the same new information may be received differently by different people or differently by the same people at different times. Inasmuch as responses to various stimuli cannot be predicted from previous stimulus-response situations or may vary among individuals, it is necessary to observe response when a stimulus (advertising, for example) is presented to consumers. Furthermore, a favorable change in attitudes of 25 per cent would not necessarily be reflected in a 25 per cent increase in the sales of a product for which the favorable attitudes were expressed. Studies of consumer attitudes serve primarily to enable us to understand and predict direction, rather than magnitude, of changes in demand..$^{10}$ Nevertheless, such information is valuable to businessmen.

SOCIOLOGICAL CONSIDERATIONS. An individual's consumption is affected by his association with reference groups which guide his behavior. Crockett indicated that one source of pressure for change originates with an individual's awareness of his deviation from a group to which he belongs. This deviation leads to a re-evaluation of his cognitions. ${ }^{11}$ Crockett found that subjects who deviate from a group will modify their attitudes toward the group norm if they are given a supporting rationale from the norm. It is through reference groups that perspectives are developed. From the perspective of the associated reference group, an individual develops his tastes and preferences.

Bourne states that buying may be either an individualistic kind of activity or largely socially conditioned. ${ }^{12}$ Consumers are said to be influenced by what others purchase, especially those with whom they compare themselves or whom they use as reference groups.

Since conspicuousness of a product is one reason for buying if the product's purchase is influenced by the buyer's reference group, it is not probable that hot cocoa, particularly for breakfast, would be greatly influenced by a reference-group relationship. Hot cocoa is usually consumed by the family under nonconspicuous conditions. Bourne listed salt, canned peaches,

\footnotetext{
${ }^{10}$ Katona, George, The Powerful Consumer, (New York: McGraw-Hill Book Company, 1960), p. 67 .

${ }^{11}$ Crockett, Walter Hobson, "The Effect of Attitude Change of Cognitive Differentiation and Affect Under Conditions of Norm-Presentation with and without Counter Arguments", in Disseration Abstracts, Vol. 13, No. 3, (Ann Arbor, Michigan: University Microfilms, 1953), p. 445.

${ }^{12}$ Bourne, Francis S., "The Concept of Reference Group Influence," The Environment of Market Behavior, (New York: John Wiley and Sons, Inc., 1964), p. 46. Holloway, Robert J. and Robert S. Hancock (eds.).
} 
laundry soap, refrigerator (brand), and radios as products where the influence of the reference group was small. Hot cocoa seems to fall in the same category. Bourne points out that purchasing in this group is governed largely by product attributes rather than by the nature of the presumed users.

Other sociological factors which influence consumer behavior include the size of the family, the occupation of the bread winner, the religion of the family, and the age of the individuals in the family group.

ANTHROPOLOGICAL CONSIDERATIONS. Culture, as described by social and cultural anthropologists, has a strong influence on consumer behavior. Researchers have become aware that within each cultural group certain patterns influence not only what foods are eaten but also other characteristics common to the group, such as clothing, housing, and social relationships. Winick has pointed to three kinds of situations in which anthropological knowledge has been employed in marketing. ${ }^{13}$ These include specific knowledge, awareness of themes of a culture, and sensitivity to taboos.

While the individuals interviewed in this study were undoubtedly influenced by both cultural and cross-cultural relationships, it is believed the period of study (four months) was too short for cultural change during this period to be a controlling factor.

OTHER CONSIDERATIONS. Most advertising takes place through mass media. In a review of studies of research concerning the effects of mass media, Klapper reported that mass media functions more often as an agent of reinforcement than as an agent of change. ${ }^{14}$ The studies reported, however, were not directed specifically to advertising but to the general effects of mass media in changing attitudes, opinions, and actions of individuals. Predispositions of individuals, that is, their existing opinions and interests, have been shown to influence their behavior to a greater extent than mass communications. ${ }^{15}$ Individuals are also apt to be selective in their exposure, perception, and retention of messages aimed at them through mass media. They tend to observe, perceive, and retain ideas and messages consonant with their existing beliefs and preferences and to re-

${ }^{13}$ Winick, Charles, “Anthropology's Contribution to Marketing,” Journal of Marketing, Vol. 25, No. 5 , (July, 1961), p. 56.

${ }_{14}$ Klapper, Joseph T., The Effects of Mass Communieation, (Glencoe, Illinois: The Free Press, 1960), p. 15.

15Ibid., p. 19 . 
ject and forget those messages which are opposed to their previously held views. ${ }^{16}$

\section{Effect of Advertising on Consumer Response}

"Advertising effectiveness" is a curious phrase, according to Halbert. ${ }^{17} \mathrm{He}$ says it is both exciting and embarrassing-exciting because of its promise, but embarrassing because it is elusive. From a duPont Company experiment involving 70,000 customer contacts, Halbert concluded that market dynamics did not permit any theory to be absolutely and permanently confirmed. He did indicate that duPont's and its competitors' market shares could be computed and said that, on this basis, gross profit for any advertising budget could be computed. ${ }^{18}$

The basis for advertising is that many wants of individuals are not inherent but are learned or acquired. Once acquired, they may be stable, but virtually none are permanent. ${ }^{19}$ Advertising theoretically supports the learning and acquiring process.

THEORETICAL RESPONSE TO ADVERTISING. Inasmuch as it was decided to use an advertising campaign for hot cocoa made with milk as a means of increasing milk consumption it appears desirable to examine the expected response from such a campaign. Such a campaign could bring an awareness of the attributes of this product to the minds of consumers. It also might serve as a reminder to others who were previously aware of these attributes. Hopefully, attitudes and beliefs (informational cue) concerning hot cocoa would be changed sufficiently that consumers' desires would reach the threshold of consumption of this product. Exposure to the advertising could serve as a triggering cue which would result in the consumption of hot cocoa.

A successful advertising program for hot cocoa made with milk would shift the demand curve for hot cocoa to the right, as indicated in Figure 1. This result would be accompanied by an increase in derived demand for its ingredients, namely, cocoa, milk, and sugar. Assuming no change in supplies of any of these products, this increased demand for hot cocoa would be reflected in higher prices for cocoa, milk, and sugar, presumably benefiting suppliers of these products. If there were no change in the

16Ibid., Chapter II.

${ }^{17}$ Halbert, Michael H., "A Practical and Proven Measure of Advertising Effectiveness," Marketing Management and Administrative Action, (New York: McGraw-Hill Book Company, 1963), p. 749. Britt, Steuart Henderson and Harper W. Boyd, Jr. (eds.).

18 Ibid., p. 758 .

${ }^{19}$ Foote, Nelson N., "The Autonomy of the Consumer" in Clark, Lincoln H. (ed.), Consumer Behavior, (New York, N.Y.: New York University Press), p. 19. 
milk supply, this increase in the derived demand for milk would give dairy farmers an opportunity to sell more milk at the relatively higher prices usually received for milk utilized as fluid milk.

\section{Empirical Studies}

Many methods have been used to test the effectiveness of advertising and promotional programs. Among these are the consumer-jury test, the inquiry test, the recognition or readership

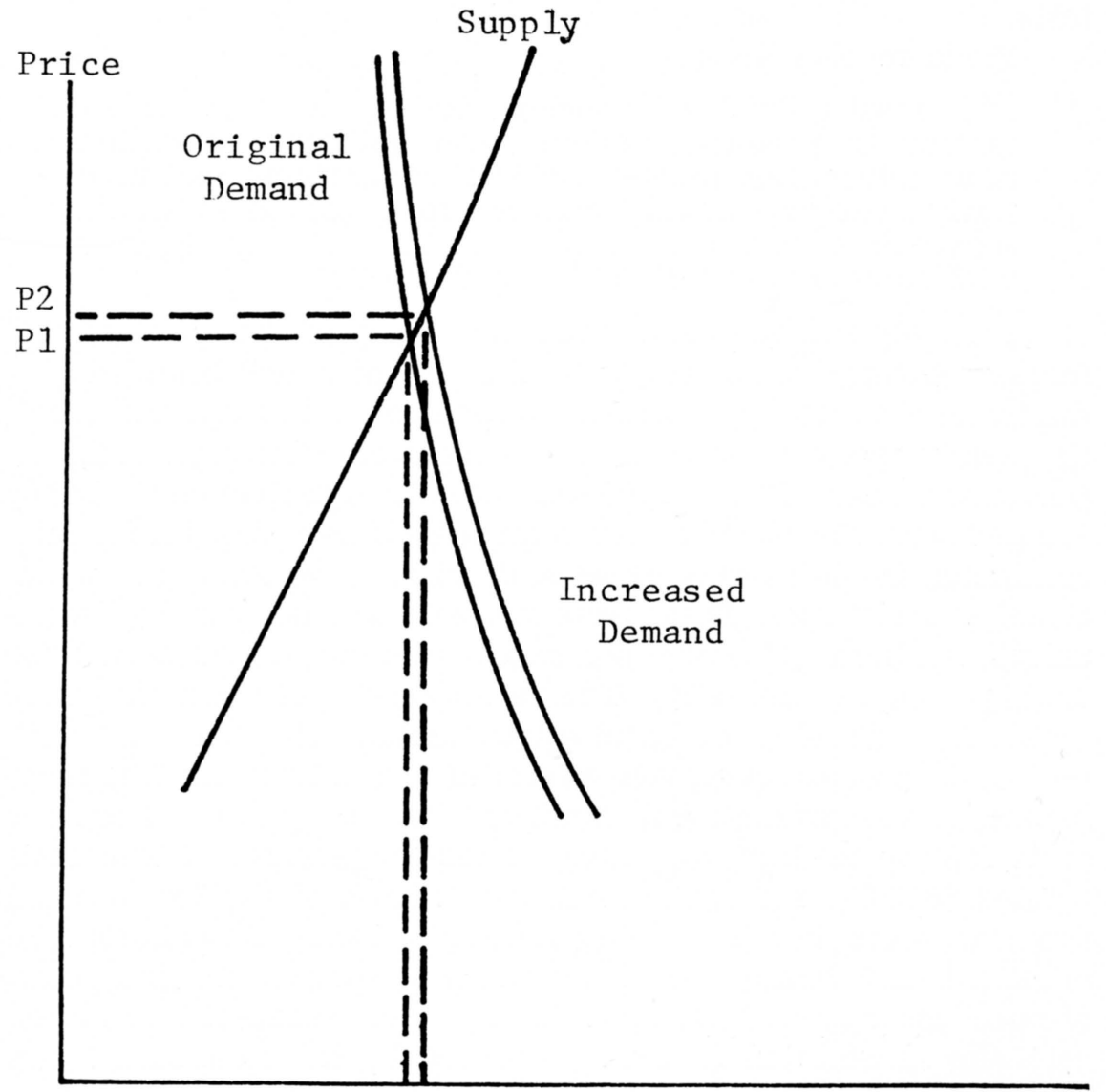

Q1 Q2

Quantity

FIGURE 1. Hypothetical demand and supply curves postulating increases in price and quantity resulting from an increase in demand. 
test, sales result test, aided-recall test, unaided-recall test, and psychological scoring. Some studies have measured the effectiveness of advertising by the number of inquiries made from coupons clipped, the recognition of themes appearing in advertising, and the response to various appeals (stimuli) appearing in advertisements. Much advertising and promotion is related to brand-identified products. Undoubtedly, many studies have been made of advertising effectiveness, particularly as it relates to sales results, but such studies usually are considered as confidential information by the firms conducting or sponsoring the tests.

Palda reports that:

. . . most published empirical studies confine their attention to problems dealing with optimum allocation of an advertising budget. These investigations deal with fairly straight forward relationships (or so it would seem) between two variables, and they usually dispense with sales as a criterion of effectiveness. ${ }^{20}$

Probably the most comprehensive study of the effect of promotion (largely advertising) on the sale of a non-branded product was conducted by Clement, Henderson, and Eley. ${ }^{21}$ Although this study was conducted after the consumer survey herein reported was made, its findings were of such significance that they are reviewed. The study involved an advertising program for milk conducted in six market areas and using three levels of promotional expenditures. These were normal ( 2 cents per capita anually), medium (15 cents per capita annually), and heavy (30 cents per capita annually). The various levels of promotion were applied in a double $3 \times 3$ Latin square design extended to a fourth period to measure carryover effects of the promotion. The magnitude of the promotional campaign can be gleaned from the costs for the medium and heavy levels of promotion. The costs totaled $\$ 673,893$ for the six markets. ${ }^{22}$ Costs of the promotional program were borne by the American Dairy Association. In addition, milk handlers in local markets sponsored some pointof-purchase material in retail stores and conducted local advertising in addition to that sponsored by the American Dairy Association.

\footnotetext{
${ }^{20}$ Palda, Kristian S., "Sales Effects of Advertising: a Review of the Literature," Journal of Advertising Researeh, Vol. 4, No. 3, (September, 1964), p. 12.

${ }^{21}$ Clement, Wendell E., Peter L. Henderson, and Cleveland P. Eley, The Effect of Different Levels of Promotional Expenditures on Sales of Fluid Milk, ERS259, United States Department of Agriculture, (Washington: United States Department of Agriculture, October, 1965). 22 Ibid., p. 15 .
} 
TABLE 1

Costs and Returns of Promotion in Six Markets March 1963 - February 1965

\begin{tabular}{|c|c|c|c|}
\hline $\begin{array}{c}\text { Level of } \\
\text { Promotion }\end{array}$ & $\begin{array}{c}\text { Cost of } \\
\text { Promotion }\end{array}$ & $\begin{array}{c}\text { Increased } \\
\text { Sales }\end{array}$ & $\begin{array}{c}\text { Net } \\
\text { Returns }\end{array}$ \\
\hline $\begin{array}{l}\text { Medium } \\
\text { Heavy }\end{array}$ & $\begin{array}{l}237,530 \\
436,363\end{array}$ & $\begin{array}{c}\text { Dollars } \\
398,580 \\
521,220\end{array}$ & $\begin{array}{r}161,050 \\
84,907\end{array}$ \\
\hline
\end{tabular}

Source: Clement, Wendell E., Peter L. Henderson, and Cleveland P. Eley, The Effect of Different Levels of Promotional Expenditures on Sales of Fluid Milk, ERS-259, United States Department of Agriculture, (Washington: United States Department of Agriculture, October, 1965), p. 15.

Clement, Henderson, and Eley found that the medium level of promotion increased milk sales 8,000 pounds per day per market over sales during the normal level of promotion. Heavy promotion increased sales 10,000 pounds per day per market over sales during the normal level of promotion. ${ }^{23}$ Additional sales of 5,000 and 7,000 pounds per day per market during a six-month period following the increased promotion levels were attributed to the medium and heavy levels, respectively.

The combined direct and carryover effects of the medium promotion level resulted in increased sales of 4.5 per cent above sales with normal promotion. The increase was 5.9 per cent in the case of the heavy level of promotion.

Costs and estimated returns from these increases in sales are shown in Table 1 . It should be noted that sales (marginal returns) increased $\$ 122,640$ with the heavy level when compared with medium level of promotion. However, costs of the promotion (marginal costs) increased $\$ 198,833$ with the heavy promotion level. Thus, marginal costs for the heavy level exceeded marginal returns which indicate the undesirability of the heavy level of promotion. The point at which marginal returns equaled marginal costs was not determined in the study.

Seaver and Hardie ${ }^{24}$ have criticized estimates of the residual and carryover effects of this advertising campaign made by Quackenbush $^{25}$ of the American Dairy Association. Essentially, the question they raised is whether the results obtained during a six-month promotion could be maintained or increased if the

23Ibid., p. 12 .

${ }^{24}$ Seaver, S. K. and I. W. Hardie, The Economies of Advertising Milk, A Speeial Case, Research Report No. 12, Connecticut Agricultural Experiment Station, (Storrs, Connecticut: The University of Connecticut, June, 1966), pp. 7-12.

${ }_{25}$ Quackenbush, Gerald, "The American Dairy Association Special Milk Promotion Test, Additional Evaluation Including Attitude and Behavior Changes." Talk presented to Board of Directors, American Dairy Association, Denver, September $21,1965$. 
level of promotion had been continued over a longer period of time. Despite this criticism, the study did quantify sales increases resulting from a specified level of promotion. Such results had not been reported previously for milk.

As an additional phase of the six-market milk promotional study, Clement and Henderson analyzed changes in consumer behavioral patterns which produced the results observed from the promotional program referred to above. ${ }^{26}$ Their study was based on consumer surveys undertaken prior to, during, and following the promotional campaign. Consumer awareness of advertising themes was measured by means of missing-word statements, in which the respondent was asked to supply the missing word in the theme. The data on recall of the advertising themes were analyzed for both the extent to which the consumers could identify the themes and the rates at which the themes were retained in later periods. Data were adjusted for guessing by respondents. With a normal-level advertising expenditure, $17.6 \mathrm{per}$ cent of the respondents correctly identified the themes, with a medium expenditure $\mathbf{5 2 . 6}$ per cent, and with a heavy expenditure 55.5 per cent.

Henderson and Clement reported that although recall of the three themes promoted in this study (milk for breakfast, milk for lunch, and milk for bedtime) increased sharply over the normal promotional level as the result of the medium and heavy promotion expenditures, the themes were not recalled to the same extent. The bedtime theme made the deepest impression on consumers. In explanation Henderson and Clement said:

Consumers may tend to accept more readily ideas which best agree with their existing beliefs. The idea of milk as a beverage for aiding sleep has long been accepted by consumers. ${ }^{27}$

They also found recall for all three themes higher among females than among males. The youngest group (15-24 years) recalled lunch and bedtime themes to a greater extent than older groups. Recall of the breakfast theme was significantly lower for the 40 -and-over age groups than for the younger groups. ${ }^{25} \mathrm{~A}$ more detailed account of this study was reported earlier by Clement. ${ }^{29}$

\footnotetext{
${ }^{26} \mathrm{Clement}$, Wendell E. and Peter L. Henderson, Consumer Response to Various Levels of Advertising for Fluid Milk, Marketing Research Report No. 805, United States Department of Agriculture, (Washington: Government Printing Office, October, 1967), p. 4.

${ }_{28}^{27}$ Ibid., p. p. 6 . $8-9$

${ }^{29}$ Clement, Wendell E., "A Study of the Advertising Process and Its Influence on Consumer Behavior," unpublished Ph.D. dissertation, American University, April, 1967.
} 
It should be noted that considerable increase in consumption of some products has taken place in the absence of advertising and promotion of the product. Borden pointed out the large increase in per capita consumption of lettuce occurring during the 21-year period, 1918-1938.: Thus, exogenous factors related to changes in consumer tastes and preferences and to consumer behavior should be considered in analytical studies of the effect of advertising on consumer demand.

The studies reviewed above attempted to measure the effects of non-brand advertising and promotion of food products. Measurement studies for other food products are listed in the bibliography. They pointed out that measuring the effect of advertising was complex due to both endogenous and exogenous variables. These studies represented serious, competent attempts to measure advertising's effect on consumer attitudes and behavior, and nearly all had pointed to limitations and problems which must be faced in clearly analyzing the effects of advertising. The remainder of this study is an attempt to apply knowledge gained to an analysis of the effect of an advertising campaign promoting the use of hot cocoa on the sale of milk.

\section{PART III}

\section{FRAMEWORK AND APPROACH OF THE STUDY}

The process by which consumers make purchases and consumption decisions has been described in Part II.

\section{Theoretical Framework}

Consumer behavior is influenced by the consumer's needs or urges. The fulfillment or satisfaction of these needs or urges usually begins with some stimilus which, in this study, is assumed to be advertising. This stimulus sets in motion a series of events during which the individual becomes aware of the attributes of a product which may satisfy his needs. These events help to change his attitudes concerning the product; and when the attitudes have been changed sufficiently, the individual changes his behavior (purchase or non-purchase, use or non-use) toward the product.

A simple diagrammatic model of these events follows (Figure 2).

${ }^{30}$ Borden, Neil H., The Economic Effects of Advertising, (Homewood, Illinois: Richard D. Irwin, Inc., 1942), pp. 364-365. 


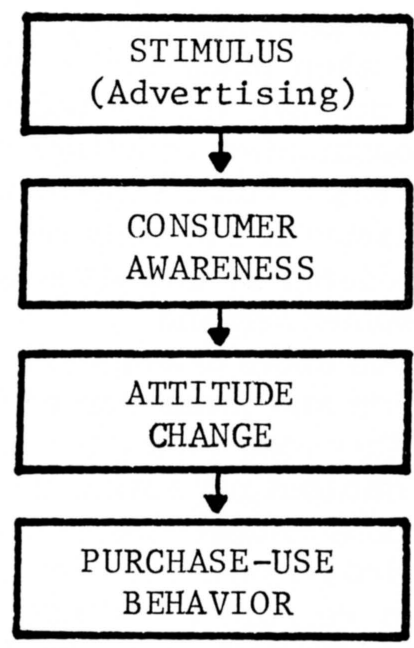

FIGURE 2. Simple model of events influencing consumer behavior.

It is recognized that extent of consumer awareness and the strength of attitude are instrumental in changing the consumer's purchase-use behavior.

The changes in consumer behavior that might result from advertising stimuli have been outlined diagrammatically by Langhoff. ${ }^{1}$ He developed a model which suggests how advertising, over time, may influence the propensity of individuals to buy or use products. ${ }^{2}$ Figure 3 portrays several possible developments which may result from consecutive exposures to advertising. In Section A of this figure, sustained exposure results in moving the consumer progressively toward the three thresholds of purchase; namely, trial, repurchase, and high product loyalty. Section B illustrates concentrated advertising exposure followed by dispersed exposure. Section $\mathbf{C}$ illustrates product failure. Exposure to advertising moved the consumer's psychological state to the trial threshold, but continued exposure resulted in a decline in willingness to accept the product. Finally, Section D depicts the effects of competitive pressure from another product or products. Even though exposure to advertising continues, the consumer's propensity to buy progressively declines.

\footnotetext{
"Langhoff, Peter, “Options in Campaign Evaluation," Journal of Advertising Research, Vol. 7, No. 4, (December, 1967), p. 45.

Ibid., p. 47 .
} 


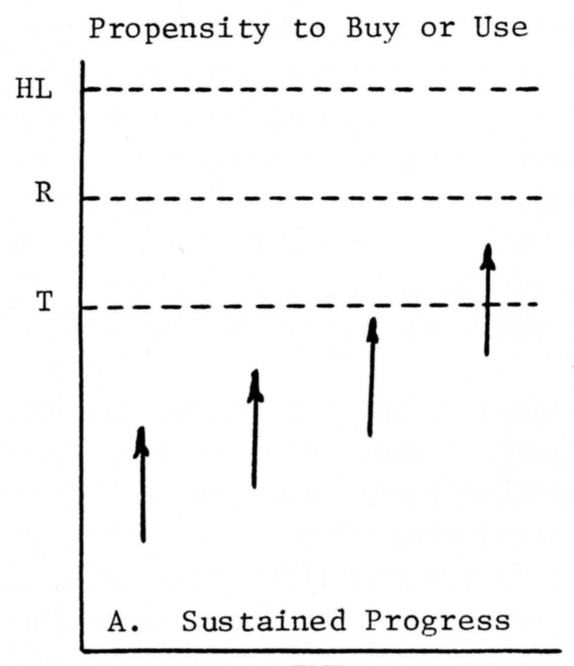

TIME

Propensity to Buy or Use

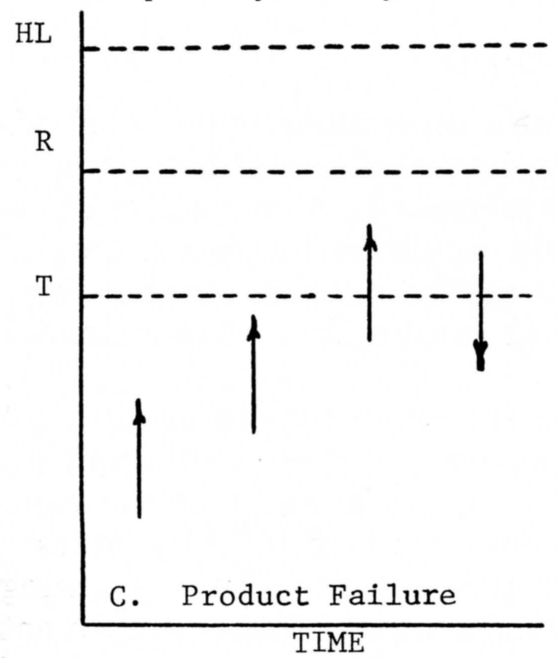

Propensity to Buy or Use

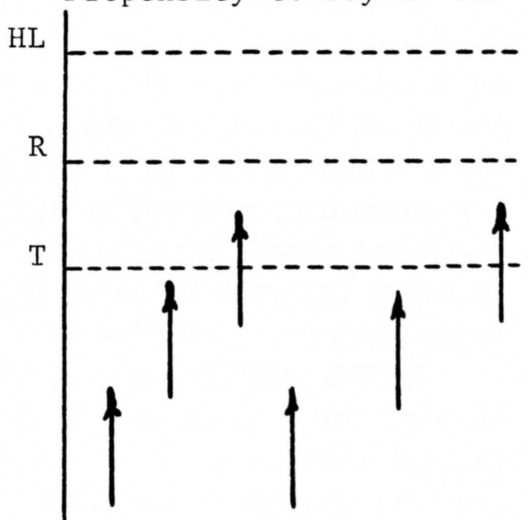

B. Concentration vs. Dispersion

TIME

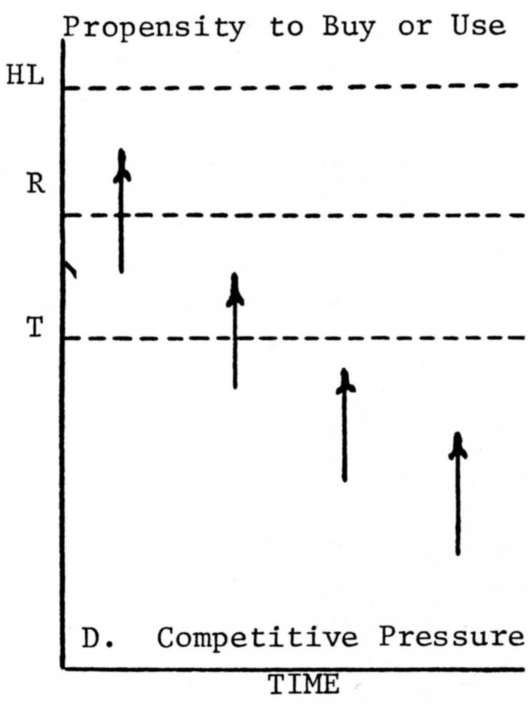

Where: HL = High Loyalty Threshold

$\mathrm{R}=$ Repurchase Threshold

$\mathrm{T}=$ Trial Threshold

FIGURE 3. Model of effect of successive exposures to advertising on propensity to buy or use product. (From: Langhoff, Peter, "Options in Campaign Evaluation," Journal of Advertising Research, Vol. '7, No. 4, Dec. 196\%, p. 4\%.) 
Two research options could have been used in this study. One was a study of the productivity of the advertising campaign as it affected use of hot cocoa and the demand for milk. The second option was to study the advertising process itself to determine what phases of the campaign were most effective in creating consumer awareness and in changing consumer attitudes toward hot cocoa. Previous training of the author and the sponsors' primary interest in sales led to major emphasis on the first of these options.

HYPOTHESES. A graphic model is used to show the relationship of the hypotheses of this study to each other and to other factors (Figure 4). A somewhat similar model was used by Clement. ${ }^{3}$ Assumptions are that the advertising stimuli (A) create an awareness of the advertising and its themes (B). Awareness, in turn, brings about an attitude change toward the product and, when the threshold level is reached, will result in use of the product (D). [Purchase is not necessarily involved since the product (hot cocoa) can be prepared from ingredients frequently found in homemaker's pantries.] Thus, the sequence of action is assumed to flow as follows:

$$
\mathrm{A} \rightarrow \mathrm{B} \rightarrow \mathrm{C} \rightarrow \mathrm{D}
$$

The major hypothesis was that a professionally designed advertising campaign would result in increased use of hot cocoa by adults. Thus, application of A will increase D. A correlative hypothesis is that the demand for milk would be increased. Several measures of the use of the product will be utilized. These include time of day consumed, frequency of consumption, and estimates of the quantities consumed.

A second hypothesis, related to the major hypothesis through the design of the advertising campaign, is that adults will increase their breakfast use of hot cocoa as a result of the campaign. Again, application of A will increase D. A third hypothesis, closely related to the first two, is that an intensive advertising campaign will increase the use of hot cocoa and that a subsequent and less intensive campaign will maintain or increase the level of use induced by the intensive campaign. Referring again to Figure 4 , the intensity of A will influence the level of D. A fourth hypothesis is that consumers will be aware of the hot cocoa advertising and the messages or themes presented in the several media

${ }^{3}$ Clement, Wendell E., "A Study of the Advertising Process and Its Influence on Consumer Behavior," unpublished Ph.D. dissertation, American University, April, 1967. p. 11. 


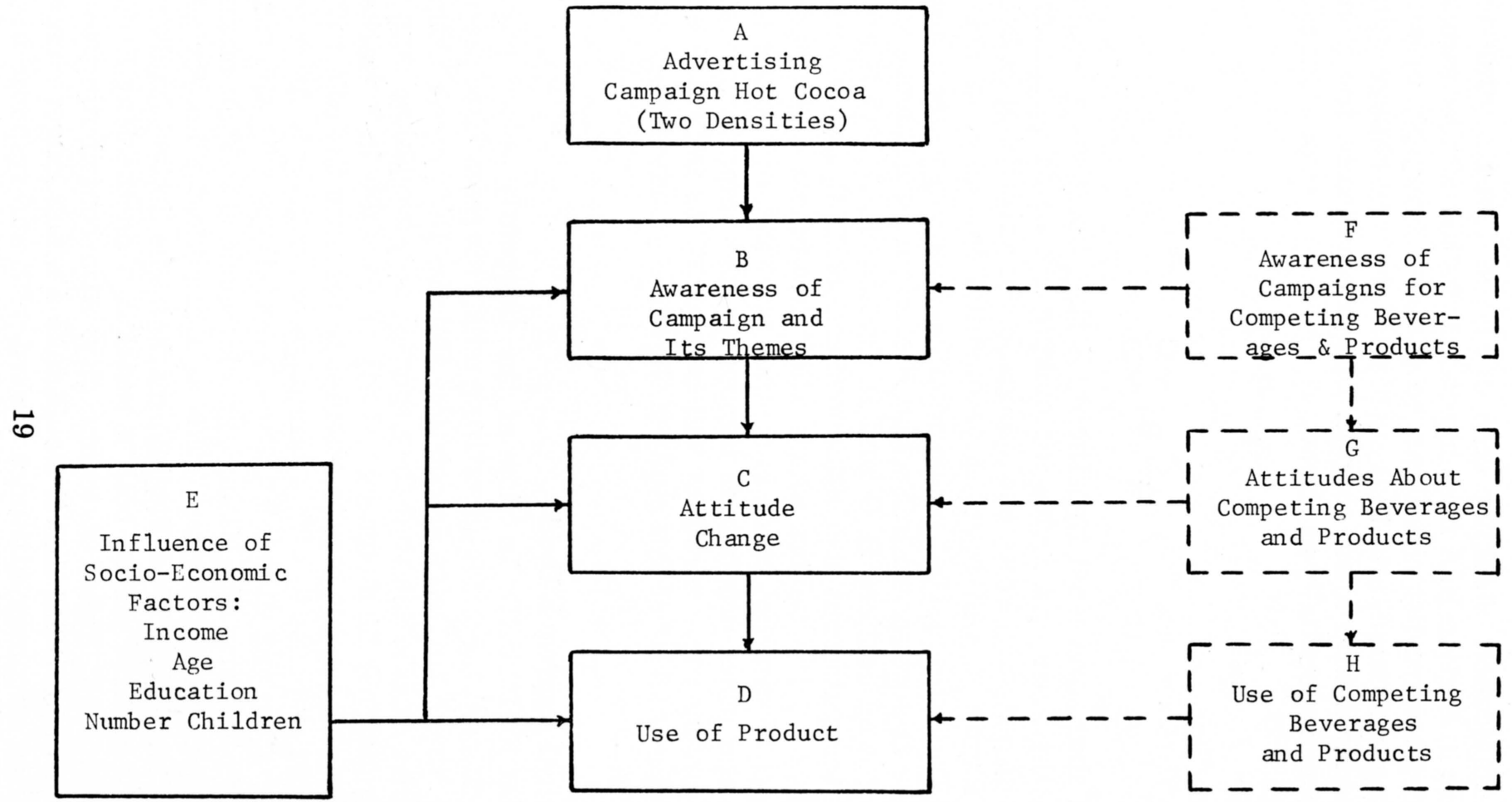

FIGURE 4. Model of events influencing consumer behavior toward hot cocoa. 
used. Application of section of A of Figure 4 would result in an increase in Section B. A fifth hypothesis is that adult consumers' attitudes toward hot cocoa can be changed favorably by an advertising campaign, and that such attitudes will change prior to or coincident with a use change. Diagrammatically, the changes will occur sequentially as shown:

$$
\begin{aligned}
\mathrm{A} \rightarrow \mathrm{B} & \rightarrow \mathrm{C} \\
\text { or } & \rightarrow \mathrm{D} \\
\mathrm{A} \rightarrow \mathrm{B}\} & \rightarrow \mathrm{C} \\
& \rightarrow \mathrm{D}
\end{aligned}
$$

A sixth, and final hypothesis, is that housewives would increase their use of a recipe for making hot cocoa recommended in the advertising. Thus, the application of advertising in Section A of Figure 4, will result in sequential increases in Sections $\mathrm{B}$ and $\mathrm{D}$, assuming that recipe adoption is one measure of use.

The factors shown in Section $\mathrm{E}$ of Figure 4 influence the effects of A on Sections B, C, and D. Sections F, G, and H are not only interrelated but also influence Sections B, C, and D. Analysis herein of all the factors which affect awareness of advertising, attitudes toward hot cocoa and other products, or the use of hot cocoa and other products is impossible, but important relationships among these variables will be sought. As indicated above, the major interest of this study is the effect of advertising on hot cocoa use.

\section{Empirical Approach Used}

BACKGROUND. In view of the frequently voiced requests for additional funds for advertising milk, this researcher proposed to the American Dairy Association and the Dairymen's Cooperative Sales Association that they sponsor an advertising campaign (or campaigns) of increased density or densities in a market or markets and permit him to attempt to measure the effect of the consumer response to such a campaign or campaigns. After much consideration and discussion, these associations, with the counsel of their respective advertising agencies, decided to sponsor an advertising campaign for hot cocoa as a breakfast drink for adults in the Charleston, West Virginia market. The limited funds available at the time placed both a restriction on the length of the campaign and limited it to one city. Also contributing to this decision was a belief that it would take a much longer campaign to change consumer attitudes toward milk and response in milk 
sales, as such. Another factor involved was that a longer campaign would be influenced more by changes in prices of the product ingredients, prices of competing products, incomes of consumers, and other exogenous variables which affect consumer demand.

THE EXPERIMENTAL METHOD. Several plans to test the hypotheses listed above were considered. It was decided to conduct "before" and "after" interviews with a random cluster sample of individuals in both test and control cities. These interviews were to be conducted simultaneously in the test and control cities to minimize any differences that might be related to seasonality of hot cocoa consumption.

It was deemed necessary to interview consumers prior to the beginning of the campaign and at the onset of cold weather, at the end of the four-week period of intensive advertising, and near the end of the twelve-week less intensive period of the advertising campaign prior to the onset of warm weather. The "before" interviews were expected to provide information concerning the existing incidence and frequency of hot cocoa consumption prior to the campaign. They were also expected to provide evidence of the consumers' attitudes which are considered one aspect of their predisposition toward the product before exposure to the advertising campaign.

It was also deemed essential to conduct another series of interviews in another market area (the control city, Clarksburg, West Virginia) at the same times to determine if seasonal or other factors tended to influence hot cocoa consumption, the beverage consumption behavior of consumers, the consumers' image of hot cocoa, the consumers' recognition of advertising themes used, and use of hot cocoa recipes by housewives.

ANALYTICAL PROCEDURES. Chi square tests were used to test the differences in interviewee responses in both the test and control cities. The interviews were conducted prior to, during, and following the advertising campaign. Chi square tests were also used to analyze the differences in responses among the several socio-economic categories into which the respondents were classified.

Multiple regression analysis was used to discover the relationships existing between the frequency of hot cocoa consumption and the socio-economic variables. A step-wise procedure of computation was used, which resulted in the determination of the most important variable affecting frequency of consumption while holding other variables constant. The second step resulted 
in the determination of the next most important variable. This procedure was continued until the variable explaining the smallest amount of the variation was found. Simple and partial correlations of relationships between variables were also computed.

Tabular analyses were made of two- and three-way classifications of the data, using the variables found to be most closely related to frequency of consumption by users and non-users of hot cocoa to determine whether other than linear relationships existed.

Measurement of changes in the volume of fluid milk sales was used to determine whether significant differences occurred in the sales during the period of the advertising campaign. An examination of changes in the economy which might have affected the incomes of consumers was undertaken. Temperature variation, as evidenced by maximum and minimum temperatures in the two market areas, were examined to determine whether changes in hot cocoa consumption during the period of study could be attributed to such variation.

SAMPLING AND STUDY AREAS. Personal and telephone interviews were chosen as the means to collect data for measuring advertising effectiveness.

THE SAMPLE. Based on the probability of relatively low incidence of hot cocoa consumption among adults, on available research resources, and on consultation with the statistician for the West Virginia Agricultural Experiment Station, the decision was made to sample approximately 1,000 households to measure consumer reaction to the advertising campaign. It was decided to interview a member of each household living within actual blocks where 75 per cent or more of the block lay within the randomly selected hypothetical blocks and also to interview a member of each household living in actual blocks whose northeast and/or northwest corner fell within the randomly selected hypothetical blocks. Interviewers were provided with sketch maps of the areas where interviews were to be made, together with the house numbers of residences within each block. These sketch maps were developed through use of the respective city directories.

One of the usual difficulties of before-and-after studies is that respondents frequently remember the answers given in the first interview and give the same answers in the second interview. This difficulty seemed to present an especially serious obstacle in this study because of the effort made during the early part of the interview questions to obscure the product with which 
the study dealt. Later in the questionnaire, the questions were directed more specifically to the product being studied. To overcome introducing a bias in the answers dealing with product characteristics and consumer attitudes, it was decided to draw another random cluster sample for the "after" interviews in each city, excluding areas which had been included in the "before" interviews. If any areas drawn in the second sample had been drawn for the "before" interviews, they were rejected and additional random drawings made. Only a limited number of areas had to be rejected as a result of this constraint. Altogether, 4,227 usable questionnaires were obtained from these samples.

Telephone interviews were used to appraise advertising effectiveness at the end of the intensive phase of the campaign. Interviewees were selected by means of a systematic sample from the page-proof of the city telephone directory and random numbers were used to select a starting point. Selection of names at the end of every seventh inch throughout the directory were estimated to yield a 1,000-respondent sample. An alternate interview list was prepared by using a similar procedure. This list was to be used if the original list failed to supply the required interviews. The telephone interviews resulted in 979 usable questionnaires.

SELECTION OF TEST AND CONTROL CITIES. Criteria used in the selection of the test and control cities were: the availability of newspapers, radio stations, and television stations for carrying the advertising; the opportunity to interview respondents in the immediate area of the media sources without going into out-ofstate areas; the willingness of the sponsors to finance the advertising campaign in specific market areas; and finally, it was believed essential for accurate analysis to locate the test and control cities far enough apart to give no opportunity in the control city for exposure to the advertising carried by any media in the test city.

Careful consideration of the above criteria led to the selection of Charleston, West Virginia, as the test city and Clarksburg, West Virginia, as the control city. These cities, located approximately 150 miles apart, are separated by a thinly populated mountainous area. Charleston radio and television programs were not received in Clarksburg, and distribution of Charleston newspapers in the city of Clarksburg was quite limited. The cities differ considerably in size, but both are populated largely by industrial workers.

THE QUESTIONNAIRE DESIGN. The questionnaire was developed in consultation with market research personnel of the 
American Dairy Association and the advertising agency which had had considerable experience in other consumer studies and advertising programs relating to milk. The questionnaire was designed to discover the beverage drinking habits of the interviewees without divulging to them the product being studied.

The questionnaire also included questions designed to determine the respondents' reasons for drinking or not drinking hot coffee, hot cocoa, and hot tea as breakfast beverages, their attitudes toward these beverages, and what they believed the attributes of these beverages were. Next, questions were posed to determine each respondent's awareness of the hot cocoa advertising and what particular advertising themes he had noted.

Finally, the socio-economic characteristics of the respondent and his family were obtained, including the number of people of various ages in his household and the type of work performed by the respondent.

A similar questionnaire was developed for the telephone interviews. This phase of the advertising campaign took place during the first four weeks of the three-month period. In this questionnaire the number of questions was reduced. The questions were limited to the beverage consumed at breakfast on the day of the interview and the frequency with which it was drunk on that day. If the beverage was hot cocoa the meal period or times of day at which it was consumed was noted. Inquiries concerning recognition of hot cocoa advertising were included. Questions pertaining to the socio-economic status of the respondents were also asked, but it was not deemed feasible to get answers to questions on race and religion.

The main objective in the telephone inquiry was to determine the current incidence and frequency with which respondents drank hot cocoa. Inasmuch as the frequency of drinking questions were asked prior to the questions on hot-cocoa advertising, it is believed that for these first questions the research interest in hot cocoa was obscured.

THE ADVERTISING CAMPAIGN. The advertising campaign for hot cocoa conducted in the test city (Charleston, West Virginia-including South Charleston, West Virginia-and hereinafter referred to as Charleston) included newspaper, radio, and television media and was scheduled as indicated in Table 2 during the winter of 1959.

It can be noted from Table 2 that the intensity of the advertising campaign was greatest in January and diminished in February and March. In the advertising by radio during the week 
beginning January 5, 50 five-second periods per week were used on each of two radio stations serving the area. One-minute advertisements appeared at a less frequent rate than the five-second announcements during the remainder of January.

The television advertising consisted of 10 Class $\mathbf{C}$ one-minute announcements and 3 Class AA 10-second announcements per week on each of two television stations serving the area during the first month of the campaign. The announcements were reduced to $\mathbf{5}$ Class $\mathbf{C}$ one-minute announcements per week on each of two stations during February and March.

The column inches of hot cocoa advertising appearing in the

\section{TABLE 2}

Media Schedule, Hot Cocoa Advertising Campaign Test City (Charleston, West Virginia)

Media and

Time Period

Advertising Schedule

\section{RADIO}

\section{Week of January 5}

WCHS $\quad 50$ five-second announcements per week

WKAZ 50 five-second announcements per week

Weeks of January 12, 19, and 26

WCHS $\quad 15$ one-minute announcements per week

WKAZ 12 one-minute announcements per week

February and March

WCHS $\quad 5$ one-minute announcements per week WKAZ 5 one-minute announcements per week

\section{TELEVISION}

January

WCHS-TV 10 Class $\mathrm{C}$ one-minute announcements per week

3 Class AA 10-second announcements per week

WSAZ-TV 10 Class C one-minute announcements per week

3 Class AA 10-second announcements per week

February and March

WCHS-TV 5 Class C one-minute announcements per week WSAZ-TV 5 Class C one-minute announcements per week

NEWSPAPER

January

February

March
3 fifty-two inch ads per week in

Charleston Gazette and Daily Mail

1 fifty-two inch ad per week in both papers

3 twenty-one inch ads per week in both papers 
newspapers was greater in January than in either February or March. During March, the advertisements were reduced from 52 to 21 column inches but appeared three times weekly which was the same frequency as during January. The main difference between the shorter and the longer advertisements was the appearance of the caricature of only one human physiognomy in the shorter advertisement as compared with three in the longer advertisement (Figure 5). The radio and television advertisements appeared when they had the most probability of reaching an adult audience: namely, early in the morning and late evening. All the advertisements were written to appeal to adults rather than to children.

ADVERTISING THEMES. All advertising media emphasized several major themes concerning hot cocoa made with milk. These included: a drink for adults; a breakfast drink; gives a quick energy lift; a lasting lift or pickup; gives you a good start; warms you up; stimulates you; easy to fix; and a recipe using a home-prepared cocoa syrup made in advance and requiring only the addition of hot milk.

\section{PART IV}

\section{CONSUMER AWARENESS OF ADVERTISING AND CONSUMER ATTITUDES TOWARD HOT COCOA}

This Part will examine and analyze first the respondents' awareness of the advertising and promotion campaign. Included will be an analysis of respondents' awareness of the advertising which took place in the different media and the respondents' recall of advertising themes carried by these media. Second, the respondents' attitudes toward hot cocoa will be examined. Those attitudes which appeared to be changed as a result of the campaign will be described. Third, possible effects of advertising on method of preparation of hot cocoa will be appraised.

A number of previous studies of advertising have been primarily concerned with the consumers' recognition of the advertising, and the general view has been that the effectiveness of advertising must start with it. Recognition would then result in changing consumers' attitudes about the product toward which the advertising was directed. Changed attitudes would move consumers to the threshold of purchase and use of the product.

Inasmuch as many of the studies have stopped with the determination of the extent of recognition of the advertising, doubt has arisen on many occasions concerning the efficacy of 
advertising in changing the direction of attitudes and increasing the purchase and use of products. Recent studies have questioned the classic pattern of a change in attitude preceding a change in behavior and some studies have reported that behavioral changes occur prior to changes in attitudes.
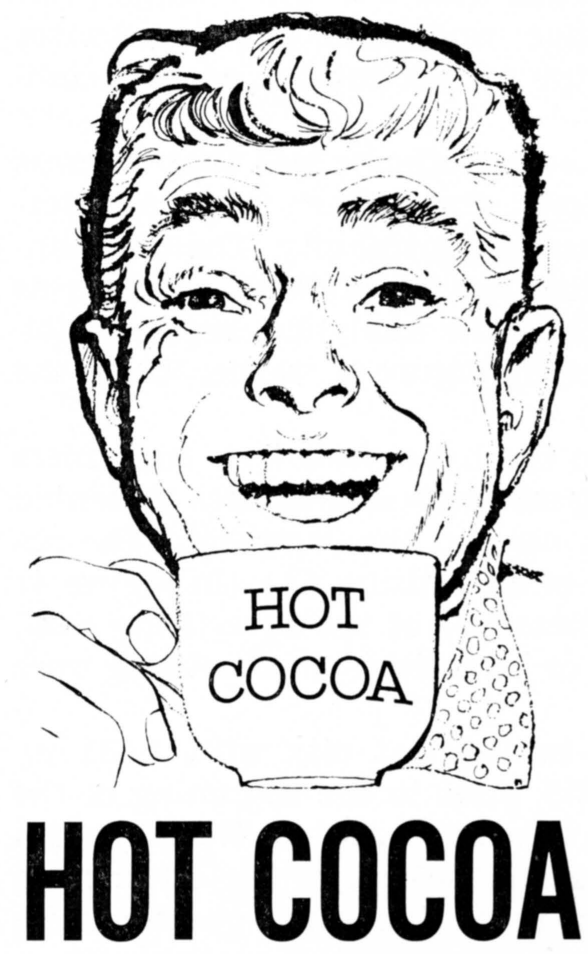

\section{made with milk FOR BREAKFAST}

Hot cocoa made with milk takes the bite out of cold winter mornings. Gives you an extrafast, lasting pick-up. Sets you up for the whole morning. And of course, made with milk, it has that lip-smacking good flavor of real old-fashioned cocoa. A wonderful way to start the day!

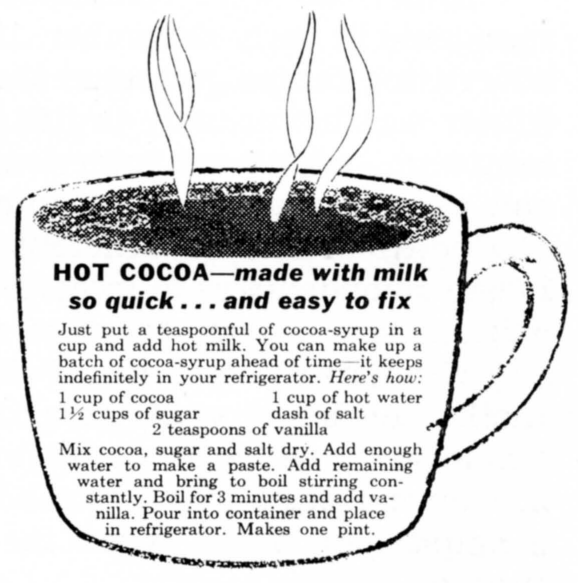

DAIRYMEN'S COOPERATIVE SALES ASSOCIATION

In Cooperation With. The American Dairy Association

FIGURE 5. Facsimile of newspaper advertisement used in hot cocoa campaign. 


\section{Hypotheses Tested}

This Part examines three of the hypotheses postulated in Part III; namely, first, that consumers would be aware of advertising messages and themes presented in the several media; second, that consumer attitudes can be favorably changed by an advertising campaign and that such attitudes will change prior to or coincident with a use change; and third, that housewives would increase their use of a recipe for making hot cocoa recommended in the advertising.

The approach in testing these hypotheses was that of cross sectional analysis based on "before" and "after" personal interviews conducted in both a test and a control city. The questionnaire was designed to obscure from the respondents, as much as possible, the research interest. Thus, the analytical sequence follows the sequence of the model in Figure 4, rather than the sequence of the questionnaire.

Attention is first directed to the hypothesis that consumers would be aware of the advertising messages and themes presented in the several advertising media used in the campaign. The objective is to test whether the use of advertising (A) (in Figure 4) would result in consumer awareness (B) of the advertising campaign and its themes. Two levels or intensities of advertising were used as described in Part III.

Interviews were conducted in the test city with 1,031 respondents in early December, 1958, prior to the beginning of the advertising campaign and at the time of year when West Virginia winter weather usually begins. Near the end of the advertising campaign, additional interviews, using the same questionnaire and as many of the same interviewers as were available, were conducted with 1,033 different respondents. In the control city, 1,064 respondents were interviewed prior to the advertising campaign. These interviews were conducted concurrently with the interviews in the test city. Following the advertising campaign, another 1,099 interviews were conducted in the control city, again concurrently with the interviews in the test city. In addition, 979 telephone interviews were conducted in the test city, following the first four weeks, when the advertising campaign was most intense.

During the course of the interviews, questions were asked about the beverages drunk at various times during the day, the breakfast beverage consumed on the day of the interview, and the frequency of hot beverage consumption (coffee, cocoa, and tea). Limited information was obtained about consumers' atti- 
tudes and opinions of the hot beverages. Many of the questions asked were of the aided-recall type. These questions gave the respondent an opportunity to select from a list of words or statements including, but not limited to, the themes emphasized in the advertising campaign. The themes carried in the advertising were dispersed among the responses which could be selected from aided-recall-reply cards. Most of the phrases were of an antonymous type, for example: supplies energy-lacks energy; drink for adults-drink for children; it's stimulating-it's relaxing; and other phrases of a like nature. There also was the opportunity for the respondent to select "none of these," "don't know" or, in the case of reasons for consuming or not consuming hot beverages for breakfast, to give reasons other than those listed on the cards.

Consumers were also asked whether they had seen, read, or heard of any sales promotion or advertising pertaining to (1) hot coffee, (2) hot cocoa, and (3) hot tea. Those who answered affirmatively for hot cocoa were then asked whether they had heard commercials about hot cocoa on the radio or had seen them on television. They also were asked if they had seen advertisements in the newspapers or magazines. In addition, they were asked if they had noticed any differences during the past few months in the way cocoa was displayed or advertised where they usually did their grocery shopping. Following each of the above questions concerning advertising or promotion, the respondent was asked to tell as much as he could remember of what he had seen, read, or heard about the commercials, the advertisements, or displays.

\section{Respondents' Awareness of Hot Cocoa Advertising or Promotion}

Interviewees were asked whether they had recently seen, read, or heard of any sales promotions or advertising of hot cocoa. Their responses are summarized in Table 3 . In the test city, the percentage of interviewees replying affirmatively to this question increased from 18.2 to 47.2 between the pre-advertising and postadvertising periods. This difference tested highly significant. The percentage response in the control city was higher (30.5) than in the test city before the advertising campaign but declined to 28.1 following the campaign. This decline, however, was not statistically significant.

Between the pre-advertising and post-advertising periods, the recognition of hot cocoa promotion or advertising was also increased in the test city by an amount testing highly significant 
among respondents who heard commercials on the radio, saw commercials on television, saw advertisements in the newspapers, or saw advertisements in magazines. Of these increases, the lowest was for those who reported seeing advertisements in magazines. No increase in recognition of advertising in magazines had been expected because no special advertising of hot cocoa in national magazines was noticed except for limited brand advertising.

During the advertising campaign, monitoring of advertisements for hot cocoa or hot chocolate was accomplished in the following seven widely distributed magzines: Better Homes and Gardens, Good Housekeeping, House and Garden, Ladies Home Journal, Life, Look, and McCalls. This search revealed only two advertisements mentioning hot cocoa or hot chocolate during this period. One was a Nestles advertisement offering 25 cents for the trial of "Nestles delicious EverReady sweet milk cocoa," which appeared in Good Housekeeping. The other was a full-page, color advertisement appearing in Better Homes and Gardens. In the latter ad, hot chocolate shared the advertisement with a lemon surprise dessert and a salad. Kraft miniature marshmallows were suggested as a desirable means of making all of these products better. Compared with the newspaper, radio, and television promotion in the test city, exposure to magazine advertising undoubtedly was minimal. The highly significant difference in respondents' recognition of advertising in magazines may have been due to the fact that this inquiry followed inquiries about recognition of advertising in the other media in which respondents had indicated a recognition of hot cocoa promotion or advertising. It has been pointed out that at times respondents want to be cooperative and attempt to give answers they think the interviewer seeks. In the test city, the proportion of respondents who noticed hot cocoa displays in the stores where they usually did their grocery shopping increased from 1.9 per cent prior to the advertising campaign to 2.5 per cent following the campaign. This difference was not significant. This non-significance was expected since little promotion in stores had been observed during weekly visits to the stores. In the control city, it was noted that, during the same period, the proportion of respondents observing hot cocoa promotions in stores increased from 1.6 per cent to 3.5 per cent. The difference was highly significant as measured by the chi-square test, but the proportions are too low to have much, if any, practical significance. The difference in the proportion of replies indicating recognition of hot cocoa promotion in 
TABLE 3

Respondents Reporting Knowledge of Hot Cocoa Advertising or Promotion by Class of Media

\begin{tabular}{|c|c|c|c|c|c|c|c|}
\hline \multirow[b]{2}{*}{$\begin{array}{l}\text { Promotion } \\
\text { Recognized }\end{array}$} & \multicolumn{3}{|c|}{ Test City } & \multicolumn{3}{|c|}{ Control City } & \multirow{2}{*}{$\begin{array}{l}\begin{array}{c}\text { Between } \\
\text { Cities }\end{array} \\
\text { Chi } \\
\text { Square } \\
\text { Results* }\end{array}$} \\
\hline & $\begin{array}{c}\text { Before } \\
\text { Adver- } \\
\text { tising } \\
\end{array}$ & $\begin{array}{r}\text { After } \\
\text { Adver- } \\
\text { tising } \\
\end{array}$ & $\begin{array}{l}\text { Chi } \\
\text { Square } \\
\text { Results* }\end{array}$ & $\begin{array}{c}\text { Before } \\
\text { Adver- } \\
\text { tising } \\
\end{array}$ & $\begin{array}{c}\text { After } \\
\text { Adver- } \\
\text { tising }\end{array}$ & $\begin{array}{c}\text { Chi } \\
\text { Square } \\
\text { Results* }\end{array}$ & \\
\hline & per cent & percent & & per cent & per cent & & \\
\hline $\begin{array}{l}\text { Any sales promotion or advertising } \\
\text { Heard commercials on radio }\end{array}$ & $\begin{array}{r}18.2 \\
1.6\end{array}$ & $\begin{array}{r}47.2 \\
9.8\end{array}$ & $\begin{array}{l}\text { HS } \\
\text { HS }\end{array}$ & $\begin{array}{r}30.5 \\
1.2\end{array}$ & $\begin{array}{r}28.1 \\
2.5\end{array}$ & $\begin{array}{l}\text { NS } \\
\text { HS }\end{array}$ & $\begin{array}{r}\text { S } \\
\mathrm{HS}\end{array}$ \\
\hline Saw commercials on television & 14.3 & 36.2 & HS & 26.6 & 23.7 & NS & NS \\
\hline Saw advertisement in newspapers & 3.4 & 23.0 & HS & 4.4 & 2.9 & NS & $\mathrm{HS}$ \\
\hline Saw advertisement in magazines & 7.0 & 11.2 & HS & 8.9 & 8.6 & NS & NS \\
\hline Observed displays in grocery stores & 1.9 & 2.5 & NS & 1.6 & 3.5 & HS & NS \\
\hline
\end{tabular}

*Code-Level of Significance: NS-not significant at the 0.05 probability level

S-significant at the 0.05 probability level

Note: Chi-square tests were computed using numbers of responses rather than percentage in this and following tables. Expression of the frequencies of replies in percentages was made to facilitate comparison. 
stores before the campaign and following the campaign was not significant between the test and control cities.

Although the interviewees in the control city who had heard commercials on the radio increased by an amount testing highly significant, the percentages responding in both the pre-advertising and post-advertising periods were quite low. During the same period, the percentages were also lower in the control city than in the test city. This difference also tested highly significant.

Between the pre-advertising and post-advertising periods in the control city, there were no significant differences in the proportions of interviewees responding to inquiries concerning observation of any hot cocoa advertising or promotion, or commercials on television, of advertisements in newspapers, or of advertisements in magazines.

RECOGNITION AT END OF INTENSIVE ADVERTISING. After the intensive phase of the advertising campaign in the test city, telephone interviews were conducted with 979 respondents. Among the questions asked during these interviews were those inquiring if the interviewee had heard or seen commercials or advertisements of hot cocoa on the radio, on television, in newspapers, and in magazines, or if he had seen displays in the grocery store where he usually did his shopping. The results of these inquiries are summarized in Table 4. For all media, substantial increases were noted in recognition of the hot cocoa advertising between the pre-advertising period and the period immediately following the intensive phase of the campaign. All of these increases tested highly significant. Although the percentages of responses to these inquiries were higher at the end of all advertising than they had been prior to it, the percentage responses were lower for all media than those obtained from the telephone interviews at the end of the intensive phase of the campaign. All the differences in percentage response between the end of the intensive campaign and the end of the entire campaign tested highly significant except for the statistic on magazines which was not significant.

It is apparent from the above that respondents were more conscious of advertising and promotion when the campaign was intense; a smaller percentage reported noting the advertising and promotions when the campaign intensity declined.

The increased percentages of respondents stating that they had observed hot cocoa advertising or promotion, particularly on the radio and in newspapers, infers that the campaign was successful in making respondents aware of its presence. For tele- 
TABLE 4

Recognition of Hot Cocoa Advertising or Promotion by Telephone Interviewees Following Intensive Advertising Phase of Campaign and Comparison with Pre-Advertising and Post-Advertising Recognition, by Class of Media

\begin{tabular}{|c|c|c|c|c|c|}
\hline \multirow[b]{2}{*}{$\begin{array}{l}\text { Promotion } \\
\text { Recognized }\end{array}$} & \multicolumn{5}{|c|}{ Test City } \\
\hline & $\begin{array}{c}\text { Before } \\
\text { Adver- } \\
\text { tising }\end{array}$ & $\begin{array}{c}\text { After } \\
\text { Intensive } \\
\text { Adver- } \\
\text { tising }\end{array}$ & $\begin{array}{c}\text { Chi } \\
\text { Square } \\
\text { Results* }\end{array}$ & $\begin{array}{c}\text { After All } \\
\text { Adver- } \\
\text { tising }\end{array}$ & $\begin{array}{c}\text { Chi } \\
\text { Square } \\
\text { Test*** }\end{array}$ \\
\hline Heard commercials on radio & percent & $\begin{array}{l}\text { per cent } \\
298\end{array}$ & HS & $\begin{array}{c}\text { per cent } \\
9.8\end{array}$ & HS \\
\hline Saw commercials on television & 14.3 & $\begin{array}{l}29.0 \\
49.3\end{array}$ & HS & 36.2 & HS \\
\hline Saw advertisement in newspapers & 3.4 & 42.9 & HS & 23.0 & HS \\
\hline Saw advertisement in magazines & 7.0 & 13.4 & HS & 11.2 & NS \\
\hline Observed displays in grocery store & 1.9 & 5.9 & HS & 2.5 & HS \\
\hline
\end{tabular}

*Code-Level of Significance: NS-not significant at the 0.05 probability level

S-Significant at the 0.05 probability level

**Testing relationship between responses in the after-intensive-advertising and after-all-advertising periods. 
vision the case is not so clear since the response in the test city, though higher after the campaign than before, was not significantly different from the response of the control city (Table 3).

\section{Obstacles to Awareness}

A low awareness of advertising hot cocoa was discovered in the analysis. One reason for this relatively low awareness of and response to the advertising stimuli by respondents may be attributed to the conditions under which the advertising stimuli reached them. Table 2 indicated that numerous messages were brought to consumers by means of radio advertisement. What this table does not show is that radio listeners were also being subjected to numerous other messages for other products.

In an attempt to hear, read, and see samples of the advertising which were being used in the hot cocoa promotion, the extent of other advertising being made available to radio listeners was periodically monitored.

During a one-hour radio program, 24 advertising messages were given. These commercials are known by such descriptions as "spot", "clutter," and "island" in the television industry. " Spot commercials are broadcast between programs or between half hours of programs lasting an hour or longer. Clutter or island commercials occur within a program. Using the same definitions for radio announcements, it would be difficult to conclude from this program what was considered "spot," "clutter," or "island" announcements.

The hot cocoa announcements of the campaign were carried on the program described above under similar circumstances. The time devoted to commercials at some periods of the day leaves little time for programs. There is no doubt that consumers' minds become cluttered with such advertisements. Under these circumstances, it is not surprising that many consumers fail to respond to the cues or stimuli the advertisements attempt to generate.

\section{Summary of Changes in Consumer Awareness, Attitudes, and Recipe Use}

CONSUMER AWARENESS OF HOT COCOA ADVERTISING. In the test city, the effect of the three-month advertising cam-

'Barclay, William D., Richard M. Doub, and Lyron T. McMurtrey, "Recall of TV Commercials by Time and Program Slot," Journal of Advertising Researeh, Vol. 5, No. 2, June, 1965, pp. 41-47. 
paign on consumer awareness was a highly significant increase in the proportion of respondents who reported noticing advertising after the campaign as compared with the period prior to it. After the first four weeks of the intensive-phase of the campaign, the effect was that a larger proportion of respondents reported awareness (seeing, reading, or hearing) of advertising or promotion of hot cocoa than reported awareness at the end of the three-month campaign period. These results applied to all three media-radio, television, and newspaper-used in the campaign. In contrast, the differences in reports for awareness of advertising in the control city were not highly significant except for that heard on the radio and of promotion seen in grocery stores. The percentage point changes in stated recognition for both radio advertising and store promotion, however, were quite low.

A highly significant change in the proportion of respondents who reported awareness of advertising in magazines also occurred despite the fact that little advertising was noted in this medium which was not used in the campaign for hot cocoa. Thus, stated awareness is not completely reliable as a measure of awareness.

The proportions of respondents who were able, without aids, to recall themes used in the advertising were quite low in both the test and control cities. Although the changes in proportions of respondents recognizing themes between the pre-advertising and post-advertising periods were quite low, in percentage points, some were highly significant.

Despite significant increases in stated awareness of advertising, respondents' ability to report the advertising themes used was quite low. The hypothesis that consumers would be aware of advertising and themes presented in the advertising is accepted. However, the small proportion of respondents who can identify advertising themes raises doubt as to the efficacy of advertising in changing consumer attitudes and behavior. These are summarized further below and in Part V.

CONSUMER ATTITUDES ABOUT HOT COCOA. The effects of the advertising campaign on the consumer attitudes and opinions, as indicated by their replies, are not entirely conclusive or uni-directional. No attempt was made to rank or scale the attitudes because of budget and time limitations during the personal interviews.

Based on frequency of responses, a number of attitudes and beliefs concerning hot cocoa was found to exist among respondents in both the test and control cities both prior to, and follow- 
ing, the advertising campaign. Those attitudes existing prior to the campaign were considered to be a measure of the respondents' predisposition toward hot cocoa. The proportion of responses given for these expressions of attitude and an indication of the degree and direction of change for the test city are given in Figure 6. In this figure, the attitudes and beliefs have been placed in two categories, (1) those considered favorable to hot cocoa consumption by adults and (2) those considered unfavorable. It should be observed that the belief that hot cocoa was a "drink for children" might be unfavorable within the context of hot cocoa as a drink for adults but might not be unfavorable if the entire market for hot cocoa is considered. As pointed out previously, the advertising campaign was designed and directed toward reaching and influencing adults.

Two statements of belief about hot cocoa: namely, that it is "nourishing" and "satisfies hunger" were given more frequently than others but were not changed significantly by the campaign. In the test city, the attitudes that hot cocoa was "good for health," "supplies energy," and was a "drink for adults" were all lower by amounts testing highly significant in the post-advertising period than prior to the campaign. The greatest favorable effect noted was the change in the belief that hot cocoa was "easy to prepare." The response that "it's stimulating" also was increased by a highly significant number of respondents, but those holding this belief made up a very small portion of the total responses on attitudes.

Among the responses considered unfavorable in the context of hot cocoa as a drink for adults was the belief that it was "a drink for children." This belief, the statement "don't like the taste," and "prefers other beverage" were all reduced during the campaign by amounts testing highly significant. This highly significant reduction of these unfavorable factors is considered to be a positive result from the advertising campaign. On the other hand, the responses "never consider for breakfast" and "hard to prepare," as a reason for not drinking hot cocoa for breakfast, both increased by small amounts but, nevertheless, tested highly significant. The increase in the response "never consider for breakfast" may have been the respondents' effort to reduce dissonance created by the campaign. Other unfavorable attitudes and beliefs showed no significant change.

The hypothesis that adult consumers' attitudes toward hot cocoa can be changed favorably toward the product was not 
FAVORABLE

Nourishing**

Satisfies hunger

Good for health

Supplies energy**

Cheap

Gives good start**

w Drink for adults**

Like tas te

It's stimulating**

Easy to prepare**

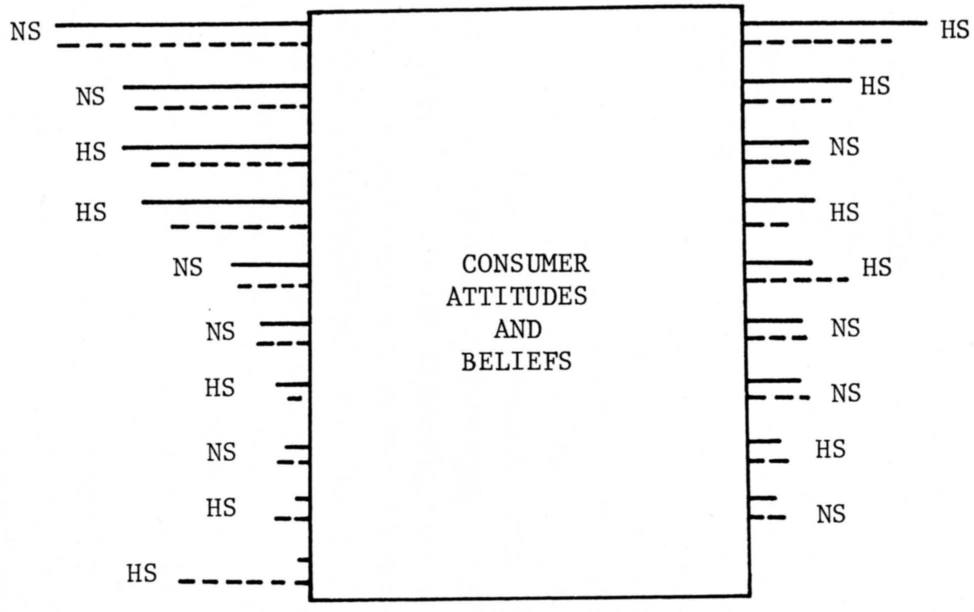

HS - Significant at the 0.01 probability leve1

NS - Not significant at the 0.05 probability leve 1 Before Advertising

--- After Advertising

FIGURE 6. Effect of advertising campaign in test city on favorable and unfavorable attitudes and beliefs about hot cocoa. 
conclusively answered by the findings in this study. Advertising apparently did influence the responses given by consumers, but the changes were both favorable and unfavorable when considered from the standpoint of the seller. The greatest proportional change in beliefs was that hot cocoa was "easy to prepare."

This finding is similar to one for milk found by Clement." Using an attitude scaling technique and regression analysis to measure the relationship of respondent statements to advertising, he found that advertising was significantly related to 24 of 25 statements made by respondents. However, 21 of these statements were adversely affected by intensified advertising. The other three were reductions in negative statements.

EFFECT OF ADVERTISING THEMES ON ATTITUDE CHANGE. Figure 6 also shows the changes in attitudes and beliefs which were closely related to some of the advertising themes. Of these, as pointed out above, "easy to prepare" showed the greatest relative change. The belief that hot cocoa was stimulating also increased by an amount testing highly significant although the absolute change in this belief was low. The beliefs that hot cocoa "supplies energy" and is a "drink for adults" both declined by amounts testing highly significant. There was no significant change in the belief that hot cocoa "gives you a good start." Again the changes were not all in the same direction. Thus, the changes which it was believed might occur in consumer attitudes were not conclusively demonstrated.

HOUSEWIVES' USE OF RECOMMENDED RECIPE. In the test city, there was a highly significant increase in the proportion of housewives who were aware of new recipes for preparing hot cocoa. The increases took place mainly among those respondents who became aware of the recipe through television advertisements and newspaper advertisements.

The proportion of housewives who reported the use of the recipe for making hot cocoa recommended in the advertising was not changed significantly. Although the advertisements indicated that the recipe recommended made hot cocoa easy to fix, no change was found in respondents' explanations concerning why they used the preparation method each employed.

The negative results obtained did not support the hypothesis that the advertising campaign would induce housewives to in-

2Clement, Wendell E., "A Study of the Advertising Process and Its Influence on Consumer Behavior," p. 187. 
crease their use of a pre-prepared syrup for making hot cocoa which was recommended in the advertising.

\section{PART V \\ APPRAISAL OF IMPACT OF ADVERTISING ON CONSUMER BEVERAGE HABITS AND MILK SALES}

This Part will analyze the changes which took place in the beverage consumption habits of respondents during the period beginning approximately a month prior to the advertising campaign and continuing to the end of the campaign. Major emphasis will be on hot cocoa consumption during this period. Several measures of cocoa use will be analyzed to determine the effect of the advertising campaign on hot cocoa consumption. These include consumption at various times of day, consumption for breakfast on the day of the interview, frequency of consumption, and estimates of the volume of hot cocoa consumed.

In addition this Part will deal with an analysis of the consumption of plain milk in the markets studied. Factors associated with consumption of both hot cocoa and milk will be analyzed as well as changes occurring in the test and control market areas during the course of the advertising campaign.

\section{Hypotheses Tested}

In this Part the major hypothesis of the study will be tested. Referring to Figure 4, the hypothesis is that a professionally designed advertising campaign for hot cocoa (A) will increase the use or consumption of hot cocoa (D). As pointed out in Part III, the advertising campaign was conducted in two intensities each of which can be considered (A) in Figure 4 . The effect of each of these intensities on the use of hot cocoa (D) and the relation of certain socio-economic factors (E) to hot cocoa use (D) will be examined. In addition, the consumption of competing beverages $(\mathrm{H})$ will be compared with that for hot cocoa consumption.

As pointed out in Part III, the advertising was directed toward promoting hot cocoa as a breakfast drink for adults. A secondary hypothesis - that the use of hot cocoa as a breakfast beverage (D) can be increased by an advertising campaign (A) which emphasizes hot cocoa in the context of a breakfast drink -will be tested.

Through emphasis on the use of milk in the preparation of hot cocoa, it was assumed that an advertising campaign which 
would increase hot cocoa consumption would likewise increase milk use.

\section{Hot Cocoa Consumption Habits}

Respondents were asked to select from a list those beverages they sometimes consumed with various meals or at other times during the day. A tabulation of the frequency of their replies which mentioned hot cocoa for the various meals or times of day is given in Table 5 .

Prior to the campaign 11.8 per cent of the respondents in the test city reported they sometimes drank hot cocoa at or before breaskfast. Following the campaign this percentage was 11.6 per cent, a nonsignificant difference. It should be noted that the advertising campaign had emphasized hot cocoa as a breakfast drink. Also to be considered is the fact that a larger portion of respondents reported sometimes drinking hot cocoa at or before breakfast prior to the campaign than at any other period. However, consumption during the evening rose from 7.9 per cent of the respondents in the pre-advertising period to 12.9 per cent at the end of the advertising period. This latter change in the test city tested highly significant. The advertising, however, had not suggested hot cocoa as either an evening or a relaxing beverage.

The proportion of respondents reporting consumption of hot cocoa at or before breakfast was at approximately the same level in the control city and did not change significantly during the period of the campaign. The differences in the proportions of the respondents drinking hot cocoa at this period were not significant between the test and control cities.

In the control city, it should be noted that the highest proportion of respondents, both before and after the campaign, reported consuming hot cocoa during the evening. The difference was not significant at this time of day. However, the percentages in the control city, 28.9 and 29.2, respectively, were higher than in the test city by an amount testing highly significant. Less than one per cent of the respondents in the control city considered hot cocoa "relaxing" and only 3.6 per cent selected "makes me sleepy" as best describing why they did not drink hot cocoa for breakfast. The only explanation found for the larger percentage of respondents who drank hot cocoa in the evening in the control city than in the test city was an apparent case of interviewer bias introduced by three interviewers 
TABLE 5

Respondents Who Sometimes Drank Hot Cocoa, by Period at Which Consumed

\begin{tabular}{|c|c|c|c|c|c|c|c|}
\hline \multirow[b]{2}{*}{$\begin{array}{c}\text { Meal or Time of } \\
\text { Day at Which Drunk }\end{array}$} & \multicolumn{3}{|c|}{ Test City } & \multicolumn{3}{|c|}{ Control City } & \multirow{2}{*}{$\begin{array}{c}\begin{array}{c}\text { Between } \\
\text { Cities }\end{array} \\
\text { Chi } \\
\text { Square } \\
\text { Results* }\end{array}$} \\
\hline & $\begin{array}{l}\text { Before } \\
\text { Adver- } \\
\text { tising }\end{array}$ & $\begin{array}{c}\text { After } \\
\text { Adver- } \\
\text { tising }\end{array}$ & $\begin{array}{c}\text { Chi } \\
\text { Square } \\
\text { Results* }\end{array}$ & $\begin{array}{c}\text { Before } \\
\text { Adver- } \\
\text { tising }\end{array}$ & $\begin{array}{c}\text { After } \\
\text { Adver- } \\
\text { tising }\end{array}$ & $\begin{array}{c}\text { Chi } \\
\text { Square } \\
\text { Results* }\end{array}$ & \\
\hline At or before & $\begin{array}{c}\text { per cent } \\
11.8\end{array}$ & $\begin{array}{c}\text { per cent } \\
11.6\end{array}$ & NS & $\begin{array}{c}\text { per cent } \\
12.2\end{array}$ & $\begin{array}{c}\text { per cent } \\
10.0\end{array}$ & NS & NS \\
\hline Between breakfast and lunch & 3.2 & 1.5 & $\mathbf{S}$ & 2.7 & 1.8 & NS & NS \\
\hline At lunch & 4.2 & 1.8 & HS & 4.9 & 5.7 & NS & HS \\
\hline During afternoon & 2.7 & 1.6 & NS & 3.4 & 2.5 & NS & NS \\
\hline At supper & 2.2 & 1.6 & NS & 5.2 & 5.4 & NS & HS \\
\hline During evening & 7.9 & 12.9 & HS & 28.9 & 29.2 & NS & $\mathrm{HS}$ \\
\hline Before going to bed & 4.2 & 4.8 & NS & 4.5 & 6.3 & NS & NS \\
\hline
\end{tabular}

*Code-Level of Significance: NS-not significant at the 0.05 probability level S-significant at the 0.05 probability level 
in the control city. However, the degree of bias appears to be constant during the pre-advertising and post-advertising periods.

A decline occurred in the percentage of respondents drinking hot cocoa between breakfast and lunch in both the test and control cities from the pre-advertising to post-advertising period. The decline in the test market was deemed significant at the 0.05 level while that in the control city was not significant.

A decline in percentage of respondents drinking hot cocoa at lunch also took place in the test city and the change from 4.2 per cent to 1.8 per cent tested highly significant. At the same time, an increase from 4.9 to 5.7 per cent occurred in the control city but this increase was not found to be significant. The numbers responding in the control city, however, were larger than those in the test city by an amount testing highly significant.

Declines in the percentage of respondents drinking hot cocoa also took place during the afternoon in both the test and control cities. These declines which occurred between the pre-advertising and post-advertising periods tested not significant in both cities. There was no significant difference between the two cities in the percentage of respondents drinking hot cocoa during the afternoon. The proportion of respondents consuming hot cocoa at supper, however, was higher in the control city than in the test city. The difference tested highly significant.

The percentage of respondents who drank hot cocoa before going to bed increased in both the test and control cities during the campaign. Neither increase tested significant, however, nor was there a significant difference between the test and control cities in the proportion of respondents drinking hot cocoa before going to bed.

HABITS AFTER INTENSIVE CAMPAIGN. During the telephone interviews conducted at the end of the intensive phase of the campaign, respondents were asked the periods at which they sometimes drank hot cocoa. Their replies are summarized in Table 6. There was no significant difference in the proportion of respondents who reported they drank hot cocoa "at or before breakfast" between the pre-advertising period and the period immediately following intensive advertising. No significant differences existed in the proportions reporting they drank cocoa "between breakfast and lunch" or "at supper" during the same period. At all other meals or times of day at which respondents 
TABLE 6

Respondents Who Sometimes Drank Hot Cocoa, by Period at Which Consumed Before Advertising, After Intensive Advertising, and After All Advertising

\begin{tabular}{|c|c|c|c|c|c|}
\hline \multirow[b]{2}{*}{$\begin{array}{c}\text { Meal or Time of } \\
\text { Day at Which Drunk }\end{array}$} & \multicolumn{5}{|c|}{ Test City } \\
\hline & $\begin{array}{l}\text { Before } \\
\text { Adver- } \\
\text { tising } \\
\end{array}$ & $\begin{array}{c}\text { After } \\
\text { Intensive } \\
\text { Adver- } \\
\text { tising }\end{array}$ & $\begin{array}{c}\text { Chi } \\
\text { Square } \\
\text { Results* }\end{array}$ & $\begin{array}{c}\text { After All } \\
\text { Adver- } \\
\text { tising } \\
\end{array}$ & $\begin{array}{c}\text { Chi } \\
\text { Square } \\
\text { Results* ** }\end{array}$ \\
\hline & percent & per cent & & per cent & \\
\hline At or before breakfast & 11.8 & 12.6 & NS & 11.6 & NS \\
\hline Between breakfast and lunch & 3.2 & 3.6 & NS & 1.5 & HS \\
\hline At lunch & 4.2 & 8.1 & $\mathrm{HS}$ & 1.8 & HS \\
\hline During afternoon & 2.7 & 5.2 & HS & 1.6 & HS \\
\hline At supper & 2.2 & 1.4 & NS & 1.6 & NS \\
\hline During evening & 7.9 & 15.9 & HS & 12.9 & NS \\
\hline Before going to bed & 4.2 & 19.1 & HS & 4.8 & HS \\
\hline
\end{tabular}

*Code-Level of Significance: NS-not significant at the 0.05 probability level

S-significant at the 0.05 probability level

**Testing relationship between responses in the after-intensive-advertising and after-all-advertising periods. 
drank hot cocoa, highly significant differences did exist between the period prior to advertising and the period immediately following the intensive campaign. Increased percentages occurred for all periods or times of day except for those reporting they drank hot cocoa "at supper." Those persons who reported they drank hot cocoa "during the evening" and "before going to bed" both had increased considerably at the end of the intensive phase of the campaign.

The proportion of respondents reporting hot cocoa consumption at the end of the three-month campaign was lower than the proportion so reporting at the end of the intensive campaign for all meals and times of day, except "at supper." The increase "at supper," however, did not test significantly different from the percentage of respondents reporting consumption following the intensive phase of the campaign. The proportion of respondents who drank hot cocoa at the end of the intensive campaign tested significantly higher than at the end of the entire campaign for hot cocoa consumption "between breakfast and lunch," "at lunch," "during the afternoon" and "before going to bed." The other increases during the same period were not significant.

Respondents' breakfast beverages on the day interviewed are shown in Table 7. Both the increase following the intensive campaign and the decrease at the end of the entire campaign tested highly significant.

\section{Frequency of Consumption of Hot Cocoa}

Respondents were asked to select from a card the frequency at which they drank hot coffee, hot cocoa, and hot tea. The proportions of respondents who indicated they drank hot cocoa at specified frequencies before and after the advertising campaign in both the test and control cities are shown in Table 8.

In the test city between the pre-advertising and the postadvertising periods the proportion of respondents who reported they drank hot cocoa one or more times a day decreased from 6.6 per cent to 4.2 per cent. As the frequency of drinking hot cocoa declined, the proportion of respondents who reported they drank hot cocoa increased in the post-advertising period as compared with the proportion for the pre-advertising period. This decline in the frequency of consumption tested highly significant.

In the control city between the pre-advertising and postadvertising periods the proportion of respondents who drank hot cocoa one or more times a day increased. Both increases and 


\section{TABLE y}

Respondents' Breakfast Beverages on Day Interviewed, Before Advertising, After Intensive Advertising, and After All Advertising

\begin{tabular}{|c|c|c|c|c|c|}
\hline \multirow[b]{2}{*}{ Beverage } & \multicolumn{5}{|c|}{ Test City } \\
\hline & $\begin{array}{l}\text { Before } \\
\text { Adver- } \\
\text { tising }\end{array}$ & $\begin{array}{c}\text { After } \\
\text { Intensive } \\
\text { Adver- } \\
\text { tising }\end{array}$ & $\begin{array}{c}\text { Chi } \\
\text { Square } \\
\text { Results* }\end{array}$ & $\begin{array}{c}\text { After All } \\
\text { Adver- } \\
\text { tising }\end{array}$ & $\begin{array}{c}\text { Chi } \\
\text { Square } \\
\text { Results } * * *\end{array}$ \\
\hline & per cent & per cent & & per cent & \\
\hline Fruit juice & 23.1 & 27.9 & $\mathrm{~S}$ & 32.1 & $\mathbf{S}$ \\
\hline Soft drinks & 0.8 & 0.2 & NS & 0.9 & $\tilde{S}$ \\
\hline Tea ............... & 4.8 & 4.8 & NS & 3.7 & NS \\
\hline Coffee & 79.5 & 76.1 & NS & 80.9 & HS \\
\hline Hot cocoa & 2.8 & 5.4 & $\mathrm{HS}$ & 1.4 & HS \\
\hline Ovaltine & 0.5 & 0.9 & NS & 0.2 & $\mathbf{S}$ \\
\hline Plain milk (unflavored) & 10.3 & 19.5 & HS & 11.9 & HS \\
\hline Flavored milk (chocolate) & 0.1 & 0.5 & NS & 0.1 & NS \\
\hline Milk drinks (malts, milk shakes) & - & 0.2 & - & - & - \\
\hline None of these & 4.3 & 2.7 & $\mathrm{~S}$ & 4.0 & $\overline{N S}$ \\
\hline
\end{tabular}

*Code-Level of Significance: NS-not significant at the 0.05 probability level

S-Significant at the 0.05 probability level

**Testing relationship between responses in the after-intensive-advertising and after-all-advertising periods. 
TABLE 8

Frequency of Consumption of Hot Cocoa, Before and After Advertising Campaign

\begin{tabular}{|c|c|c|c|c|}
\hline \multirow[b]{2}{*}{$\begin{array}{l}\text { Frequency } \\
\text { Indicated }\end{array}$} & \multicolumn{2}{|c|}{ Test City } & \multicolumn{2}{|c|}{ Control City } \\
\hline & $\begin{array}{l}\text { Before } \\
\text { Adver- } \\
\text { tising }\end{array}$ & $\begin{array}{l}\text { After } \\
\text { Adver- } \\
\text { tising }\end{array}$ & $\begin{array}{c}\text { Before } \\
\text { Adver- } \\
\text { tising }\end{array}$ & $\begin{array}{l}\text { After } \\
\text { Adver- } \\
\text { tising }\end{array}$ \\
\hline $\begin{array}{l}\text { One or more times a day } \\
\text { Less often than once a day }\end{array}$ & $\begin{array}{c}\text { percent } \\
\quad 6.6\end{array}$ & $\begin{array}{l}\text { per cent } \\
\quad 4.2\end{array}$ & $\begin{array}{l}\text { percent } \\
5.7\end{array}$ & $\begin{array}{l}\text { per cent } \\
\quad 6.2\end{array}$ \\
\hline $\begin{array}{l}\text { but more often than once a week } \\
\text { Less than once a week but }\end{array}$ & 14.3 & 15.4 & 17.1 & 16.0 \\
\hline $\begin{array}{l}\text { more often than once a month } \\
\text { Less than once a month } \\
\text { Never }\end{array}$ & $\begin{array}{l}12.1 \\
17.2 \\
49.8\end{array}$ & $\begin{array}{l}16.6 \\
21.6 \\
42.2\end{array}$ & $\begin{array}{l}14.5 \\
19.4 \\
43.2\end{array}$ & $\begin{array}{l}15.6 \\
15.9 \\
46.3\end{array}$ \\
\hline
\end{tabular}

Chi-square results:*

Between before advertising and after advertising: Test City — HS

Control City - NS

Between Cities - NS

*Code-Level of Significance: NS-not significant at the 0.05 probability level

S-significant at the 0.05 probability level 
decreases occurred for the remaining frequencies, but the statistical test showed no significant difference between proportions who drank hot cocoa at the several frequencies in the control city.

Comparisons of the consumption frequencies between the test and control cities also showed no significant difference in the proportions of respondents who drank hot cocoa.

FREQUENCY AFTER INTENSIVE CAMPAIGN. Identical questions were asked about the frequency of consumption of hot beverages during the telephone interviews conducted after the intensive phase of the campaign. It was not possible to provide respondents with any recall device such as the cards used in the person-to-person interviews. The proportions of respondents classified by their frequency of hot cocoa consumption are shown in Table 9.

The frequency of hot cocoa consumption increased between the pre-advertising and post-intensive advertising periods. Despite this, the frequency of hot cocoa consumption declined between the post-intensive advertising period and the end of the entire advertising campaign. Both the increase and the subsequent decrease in frequency of consumption tested highly significant.

Evidence of reliability of information obtained by telephone interviews has ranged from high reliability of advertising awareness to low reliability on confirmation of brand purchased when data were compared with pantry inventories of the same products.

On the other hand, Metz reported that respondents overstated their milk purchases by 13.5 per cent when data from person-to-person interviews were compared with distributor delivery records. ${ }^{1} \mathrm{He}$ also found data on milk purchases to be less reliable as the number of days increased between the date of purchase and the date of the interview.

Thus, neither person-to-person interviews nor telephone interviews may be considered completely reliable sources of consumption data.

\section{Relationship of Socio-Economic Factors to Hot Cocoa Consumption}

A number of socio-economic characteristics of the respond-

${ }^{1}$ Metz, Joseph F., Jr., Methods of Research in Marketing, Paper No. 5, Department of Agricultural Economics, Cornell University, Ithaca, New York, July, 1956, p. 14 . 
ents were obtained during the course of the interviews. These characteristics were cross tabulated with the hot cocoa consumption habits of the respondents. This was done for those respondents who drank hot cocoa on the day interviewed, for those respondents who sometimes drank hot cocoa, and for other consumption factors examined in the study. The limited number of respondents who drank hot cocoa on the day interviewed provided so little data that analysis would be meaningless. Inasmuch as more respondents sometimes drank hot cocoa, an analysis was made of the socio-economic characteristics of respondents with this consumption habit.

Among the socio-economic characteristics obtained were size of family, number of children in family, family income level, education level of respondents, respondent's position in the household, type of employment, color, age, religious preference, and nationality background. Of these, only the significance levels of the relationships between education attainment, number of children in the family, age, and family income level are shown in Table 10. Except for a non-significant relationship between the levels of family income and the proportions of respondents who sometimes drank hot cocoa in the pre-advertising period in the test city, all other characteristics showed a highly significant or significant relationship to the proportions of respondents who drank hot cocoa. This means that in nearly all cases there is some relationship between the proportion of respondents who sometimes drink hot cocoa and age, number of children, education level, and family income. However, it does not include the degree of relationship existing. Further analyses of these relationships are presented elsewhere. ${ }^{2}$

\section{Milk Sales in Market During Campaign}

Class I milk sales volume in the test market, at the time of this study, had been rising for a number of years. Unpublished data of the West Virginia Agricultural Experiment Station also indicate that a definite seasonal pattern exists and that this pattern has varied from time to time. In order to estimate the effect of the advertising campaign on Class I milk sales, trend values were computed for the ten-year peirod, 1950-1959. A seasonal index also was computed from data for the same period.

"Clarke, James H. "Effect of an Advertising Campaign on Hot Cocoa Consumption," Unpublished Ph.D. Thesis, University of Minnesota, March, 1969. pp. $165-188$. 
TABLE 9

Frequency of Consumption of Hot Cocoa Following Intensive Phase of Advertising Campaign

\begin{tabular}{|c|c|c|c|}
\hline \multirow[b]{2}{*}{$\begin{array}{c}\text { Consumption } \\
\text { Frequency }\end{array}$} & \multicolumn{3}{|c|}{ Test City } \\
\hline & $\begin{array}{l}\text { Before } \\
\text { Adver- } \\
\text { tising }\end{array}$ & $\begin{array}{l}\text { After } \\
\text { Adver- } \\
\text { tising }\end{array}$ & $\begin{array}{c}\text { After All } \\
\text { Adver- } \\
\text { tising }\end{array}$ \\
\hline One or more times a day & $\begin{array}{l}\text { per cent } \\
\quad 6.6\end{array}$ & $\begin{array}{l}\text { per cent } \\
\quad 9.6\end{array}$ & $\begin{array}{l}\text { per cent } \\
\quad 4.2\end{array}$ \\
\hline $\begin{array}{l}\text { Less often than once a day } \\
\text { but more often than once a week }\end{array}$ & 14.3 & 16.8 & 15.4 \\
\hline $\begin{array}{l}\text { Less than once a week } \\
\text { but more often than once a month } \\
\text { Less than once a month } \\
\text { Never }\end{array}$ & $\begin{array}{l}12.1 \\
17.2 \\
49.8\end{array}$ & $\begin{array}{l}15.9 \\
16.7 \\
41.0\end{array}$ & $\begin{array}{l}16.6 \\
21.6 \\
42.2\end{array}$ \\
\hline
\end{tabular}

Chi-square results:*

Between before advertising and after intensive advertising - HS

Between after intensive advertising and after all advertising - HS

*Code-Level of Significance: NS-not significant at the 0.05 probability level

S-significant at the 0.05 probability leve
HS-significant at the 0.01 probability leve 
TABLE 10

Levels of Significance for Relationship Between Hot Cocoa Consumption and Selected Socio-Economic Characteristics

\begin{tabular}{|c|c|c|c|c|c|}
\hline \multirow[b]{2}{*}{$\begin{array}{l}\text { Socio-Economic } \\
\text { Characteristic }\end{array}$} & \multicolumn{2}{|c|}{ Test City } & \multicolumn{2}{|c|}{ Control City } & \multirow{2}{*}{$\begin{array}{c}\text { Both Cities } \\
\text { Before and } \\
\text { After } \\
\text { Adver- } \\
\text { tising }\end{array}$} \\
\hline & $\begin{array}{c}\text { Before } \\
\text { Adver- } \\
\text { tising }\end{array}$ & $\begin{array}{c}\text { After } \\
\text { Adver- } \\
\text { tising }\end{array}$ & $\begin{array}{c}\text { Before } \\
\text { Adver- } \\
\text { tising }\end{array}$ & $\begin{array}{c}\text { After } \\
\text { Adver- } \\
\text { tising }\end{array}$ & \\
\hline & \multicolumn{5}{|c|}{ level of significance ${ }^{*}$} \\
\hline Age of respondent & HS & HS & HS & HS & HS \\
\hline Number of children in family & HS & HS & HS & HS & HS \\
\hline Education level of respondent & HS & HS & HS & HS & HS \\
\hline Family income & NS & HS & HS & $\mathrm{S}$ & HS \\
\hline
\end{tabular}

*Code-Level of Significance: NS-not significant at the 0.05 probability level

S-significant at the 0.05 probability level

(Contingency chi-square analysis) 
The adjusted sales volume for each month was obtained by adjusting the trend value by the seasonal index for the same month. The differences between the adjusted sales volume and the actual sales volume were determined for each month. The changes as a percentage of the adjusted sales volume were then computed. These indicated that for the period, January to March, 1959, sales volume of Class I milk was lower than might have been expected. It was noted, however, that sales volumes in each of the other quarters of 1959 were relatively lower than during the quarter in which the campaign was conducted.

EFFECT OF HOT COCOA CONSUMPTION ON MILK SALES VOLUME. In the test city between the pre-advertising and postintensive advertising periods, estimates indicated that hot cocoa consumption increased 22.1 cups per person on an annual basis, or 33.5 per cent. If this increase is applied to the estimated 566,000 people who lived in the market area ${ }^{3}$ in 1959 , it would result in an increase for the year of $6,605,280$ pounds. This would have been about 18,097 pounds daily, or an increase of about 7.9 per cent from the pre-advertising period to the post-intensive advertising period.

The estimates, however, also indicate that by the end of the advertising period, hot cocoa consumption had declined 10 cups per person on an annual basis from the level prevailing in the pre-advertising period. Thus, all of the estimated gain made during the intensive phase of the campaign was lost, plus the 10 cups per person indicated above. In total, the decline was about 3.6 per cent for the three-month campaign period.

The percentages of gain and loss above were computed using the daily average Class I milk sales volume. The percentages may be slightly over-stated since the distributors in the test city were not the only distributors serving the market area. Data for sales by other distributors were not available.

COSTS AND RETURNS. Approximately $\$ 20,000$ was spent on the advertising campaign for hot cocoa in the test city during the three months, January to March, 1959. During the first four weeks of the campaign, slightly more than one-half of the advertising exposures of the entire campaign were presented to the audience in the test city. The percentages of total advertising of hot cocoa presented during the first four weeks of the campaign, for each class of media were: radio- $\mathbf{5 2 . 5}$ per cent, television-

${ }^{3}$ Includes the counties of Boone, Fayette, Kanawha, Lincoln, Logan, Putnam, Raleigh, and Wyoming. 
$\mathbf{5 1 . 2}$ per cent, and newspapers-57.6 per cent. More than one-half $(\$ 11,000)$ of the total was budgeted for the first four weeks of the campaign.

The increase in estimated consumption of hot cocoa at the end of the intensive phase of the campaign would result in shifting milk from the low-priced federal milk market order classifications into the high-priced Class I category. The difference between the price for Class I milk and the price for milk in other classifications in the test market was $\$ 2.34$ per hundredweight. During January, Class I sales volume would have increased by approximately 561,000 pounds or 5,610 hundredweight. At the above price difference, farmers would have received an additional $\$ 13,127$ for their milk. This would have been a gross monetary gain from advertising, granting the validity of the estimates above, of $\$ 2,127$.

The advertising campaign, however, did not stop following its intensive phase but continued through February and March. At the end of the entire campaign, it was estimated that the volume of hot cocoa consumption was 3.6 per cent lower than prior to the campaign. If this loss is charged to the campaign, the total cost to farmers would have been $\$ 5,544$ plus the $\$ 20,000$ spent on advertising minus $\$ 2,127$ (the gain for the first four weeks) or a net loss of $\$ 23,417$. Obviously under the situation in the test market, advertising should be intensive.

\section{Milk Consumption Habits}

Although the main emphasis in this study was the effect of the hot cocoa advertising campaign on consumer image of hot cocoa and on hot cocoa use, some interesting discoveries were made relative to consumption of plain milk in the markets studied. Plain milk was defined as pasteurized or pasteurized-homogenized-unflavored whole milk ordinarily consumed as fluid milk. The proportions of respondents who sometimes drank plain milk with meals or at other times of the day prior to and following the hot cocoa advertising campaign in the test and control cities are shown in Table 11.

Statistically significant changes in the proportion of respondents who sometimes drank milk occurred for three periods in the test city during the campaign. The proportion drinking milk "at lunch" increased while declines were noted in the proportions who drank milk "between breakfast and lunch" and "during the afternoon."

In the control city a significant decline occurred during the 
TABLE 11

Respondents Who Sometimes Drank Plain Milk, by Period at Which Consumed

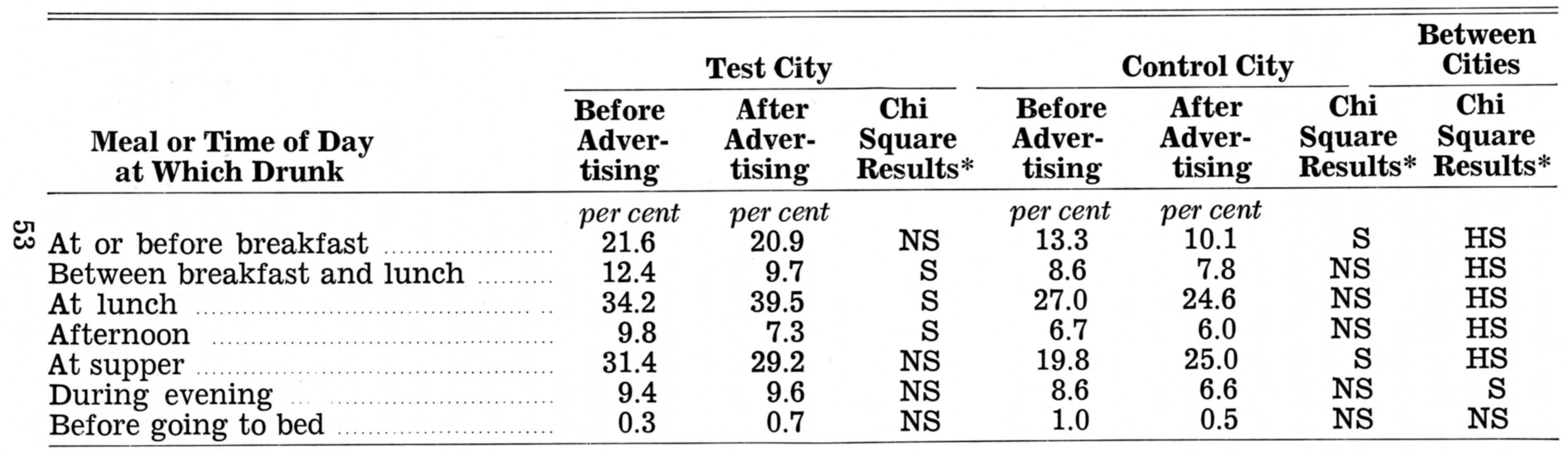

*Code-Level of Significance: NS-not significant at the 0.05 probability level

S-significant at the 0.05 probability level 
campaign in the proportion of respondents who drank milk "at or before breakfast." During the same period the proportion who drank milk "at supper" increased.

An interesting fact shown in this table is that for all times milk was consumed, except "before going to bed," the proportion of respondents consuming milk in the test city was higher than in the control city by amounts testing significant or highly significant. The proportion consuming milk "before going to bed" was one per cent or less of the respondents in all cases and the difference between cities for this period was not significant.

The proportion of respondents who drank milk "at or before breakfast" on the day interviewed increased from 10.3 to 19.5 per cent during the period starting prior to the campaign and ending after the intensive phase of the campaign. This difference was highly significant.

Two factors appear to be associated with the larger porportion of respondents who drank milk in the test city than in the control city. First, the producer members of the Dairymen's Cooperative Sales Association in the test market had spent more money in advertising milk over a longer period of time than had their fellow producer members in the control (Clarksburg) market. Second, and a somewhat weaker reason, was the fact that the incomes of respondents were higher in the test city than in the control city by an amount testing significant.

No satisfactory explanation was found for the increase in the proportion of consumers who drank plain milk "at or before breakfast" on the day of the interview, following the intensive phase of the campaign, as compared with the proportion who drank plain milk prior to the campaign. Incomes of respondents to the telephone survey, conducted at the end of the intensive phase of the campaign, were lower by an amount testing highly significant as compared with incomes of respondents interviewed in the person-to-person interviews before the campaign.

Thus, these lower incomes, in view of the income elasticity of demand for milk shown earlier, would tend to support use of milk by a lower proportion of respondents in the post-intensive phase interviewee group rather than explain the greater proportion of this group who drank milk.

ADVERTISING EXPENDITURES FOR MILK. Over the seven-year period (1952-1958) preceding the hot cocoa advertising campaign, producer members of the Dairymen's Cooperative Sales Association and the milk processors they supplied in the 
test market had supported advertising and promotion of unbranded milk by substantial expenditures. During this period, the producers contributed one and one-half cents per hundredweight to the Dairy Council, two cents per hundredweight to local advertising, and two cents per hundredweight to the American Dairy Association for national advertising and promotion. Milk processors contributed another one and one-half cents per hundredweight to the Dairy Council. ${ }^{4}$

Average annual production in the test market during this seven-year period was $\mathbf{8 8 . 2}$ million pounds. Thus, over this period producers would have spent approximately $\$ 17,640$ annually on local advertising while the Dairy Council would have had an additional \$26,460 annually for promotion. Over the seven-year period, these two expenditures would have totaled $\$ 308,700$.

In the control city, producers had expended one cent per hundredweight for Dairy Council over a five-year period and two cents per hundredweight for advertising over the seven-year period (1952-1958). Average annual production in the control market was 27.7 million pounds. Thus, producers in this market have collected $\$ 5,540$ annually for advertising. However, out of this they contributed an average of $\$ 1,012$ annually to the American Dairy Association for national advertising and promotion. This left an annual net of $\$ 4,528$ for local advertising. In addition to this, producers contributed $\$ 2,768$ annually to the Dairy Council, which was used largely for local promotion. Altogether producers in this market contributed $\$ 45,536$ to advertising and promotion activities over the same seven-year period. This total for the control city was $\$ 263,164$ less than in the test city over the entire seven-year period or $\$ 37,595$ less annually. It is evident, therefore, that the higher advertising and promotion expenditures in the test city than in the control city were related to the higher proportion of respondents in the test city who drank plain milk. Whether this relationship was causal is not clear from these facts alone. Other relationships existing in the test and control markets have previously been reported. Family incomes were somewhat higher in the test market but, in view of the low income elasticity for milk, could probably not account for the difference in milk drinking behavior of respondents in the two cities.

${ }^{4}$ Letter to the author from the late George A. Taylor, then Manager of the Dairymen's Cooperative Sales Association, dated November 22, 1960. 


\section{Summary of Impact of Advertising on Behavior}

This Part tested the effect of advertising on the use of hot cocoa and examined selected factors associated with hot cocoa consumption. Part IV indicated both a low level of and little change in awareness of the advertising campaign. Attitudes following exposure to the advertising also changed little. Hence, this part tested the effect of advertising on use of hot cocoa even though awareness and attitudes were not changed greatly as contemplated in the model in Figure 4.

CONSUMER USE OF HOT COCOA. Consumer use of hot cocoa was measured in three ways. These included the proportion of respondents who sometimes drank hot cocoa, the proportion of respondents who drank hot cocoa for breakfast on the day interviewed, and the frequency with which respondents drank hot cocoa.

EFFECT OF INTENSIVE CAMPAIGN. From prior to the campaign to the end of the four-week intensive advertising campaign, the proportion of respondents in the test city who reported sometimes using hot cocoa increased by highly significant amounts. Increases were noted for the following times of day: "at lunch," "during afternoon," "during evening" and "before going to bed." These changes are presented diagrammatically in Figure 7.

At the end of the same period of intensive advertising, compared with the period prior to advertising, the proportion of respondents who drank hot cocoa and milk for breakfast on the day interviewed also had increased by highly significant amounts.

Frequency of consumption increased during the intensive phase of the campaign. It was estimated that the volume of hot cocoa consumed increased about one-third during this period. Class I milk sales would have increased 7.9 per cent and farmers would have gained $\$ 2,127$ above advertising costs as a result of shifting milk from lower- to higher-priced uses.

The hypothesis that an intensive advertising campaign will increase the use of hot cocoa is accepted. It also is apparent that the use of a product may be changed even though the respondents' awareness of the campaign is limited and his attitudes largely unchanged.

EFFECT OF ENTIRE CAMPAIGN. Significant changes in proportions of respondents' stated use of hot cocoa in the test city are summarized in Figure 7. For the entire three-month campaign, there was a decline in the proportion of respondents 


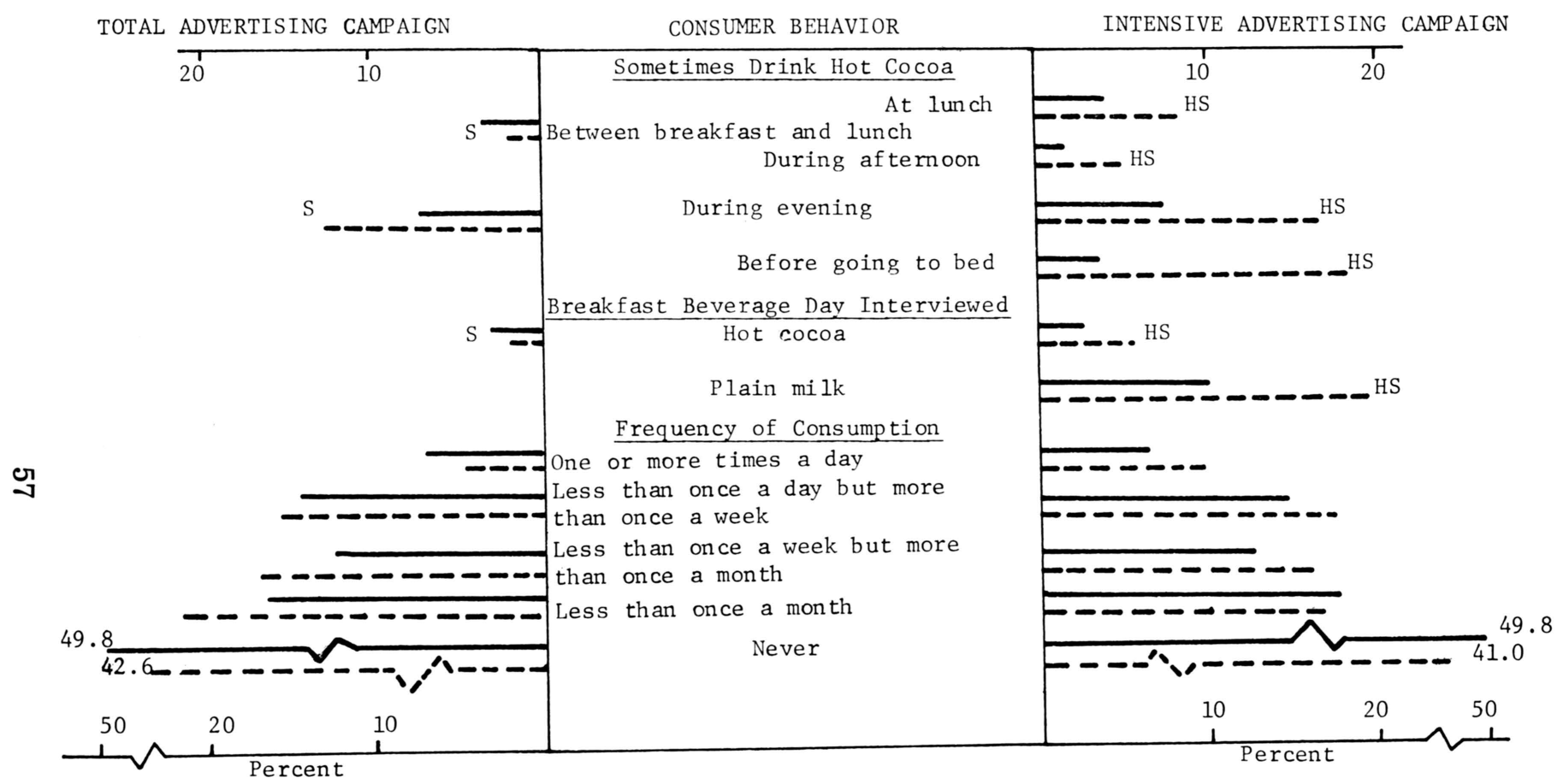

NS - not significant at the 0.05 level; S - significant at the 0.05 leve1; HS - significant at the 0.01 level. before advertising; after advertising.

FIGURE \%. Effect of advertising campaign in test city on consumer behavior toward hot cocoa and milk. 
who drank hot cocoa "between breakfast and lunch" and an increase in the proportion who drank hot cocoa "during the evening." The proportion who drank hot cocoa for breakfast on the day interviewed also declined significantly. Frequency of consumption of hot cocoa was lower at the end of the campaign than prior to it. In the test city, estimated volume of hot cocoa consumption was 15 per cent lower at the end of the campaign than before it started. Producers' advertising costs and losses of revenue from sales after the entire campaign were estimated at $\$ 23,417$. This amount was adjusted for the gain made during the intensive phase of the campaign.

The hypothesis that an entire advertising campaign for hot cocoa of the type tested will increase the use of hot cocoa is rejected. The findings do not completely support the model of events outlined in Figure 4. Intensive advertising, however, did appear to follow the model and to result in increased revenue for the farmers who sponsored it.

FACTORS ASSOCIATED WITH HOT COCOA CONSUMPTION. As indicated in the model of events influencing consumer behavior toward hot cocoa (Figure 4) it was assumed that selected socio-economic factors (E) would influence the use of hot cocoa. The relationship of these factors to hot cocoa consumption was tested by tabular analysis, multiple correlation analysis, and analysis of variance. The tests indicated that these factors accounted for only a small proportion of the variation in hot cocoa use. The highest coefficient of determination $\left(R^{2}\right)$ between the frequency of hot cocoa consumption and the independent variables of age, education level, family income level, and number of children in the family was 0.0654 . Three-way cross tabulations indicated no curvilinear relations existed between hot cocoa use and the independent variables listed above.

Inasmuch as both the frequency of hot cocoa and three of the four socio-economic factors had been classified by groups, analysis of variance procedures were used to locate the variance. Although a number of the classification variables (age, education level, family income and number of children in the family) had significant or highly significant $F$ ratios, it was estimated that the maximum variance in hot cocoa consumption which could be accounted for by a single classification variable was $\mathbf{5 . 5 9}$ per cent. The error sums of squares were quite large, indicating that most of the variance was not explained by the classification variables used. Of the classification variables analyzed, only that 
for age showed a consistent relationship to hot cocoa consumption. Individuals in the younger age groups consumed more hot cocoa. This is somewhat surprising in view of the determination that the highest proportions of individuals who considered hot cocoa "good for health" were in the older age groups.

EXTERNAL INFLUENCES. During the period of the campaign, economic conditions in the markets studied were favorable to increased consumption of hot cocoa. Temperatures in the markets studied were examined and it was believed that the existing variations would not have influenced hot cocoa consumption greatly.

EFFECT OF ADVERTISING ON MILK SALES. A significantly higher proportion of respondents in the test city reported drinking milk than in the control city. The proportions who reported drinking milk did not appear to be affected by the hot cocoa advertising campaign. It was discovered, however, that over a seven-year period the producers in the test city had spent $\$ 37,595$ more per year for advertising and promoting milk sales than had producers in the control city.

\section{BIBLIOGRAPHY}

\section{Books}

Borden, Neil H. The Economic Effects of Advertising. Homewood, Illinois: Richard D. Irwin, Inc., 1942.

Bourne, Francis S. "The Concept of Reference Group Influence," The Environment of Market Behavior, Holloway, Robert J. and Robert S. Hancock (eds.). New York: John Wiley and Sons, Inc., 1964.

Britt, Steuart Henderson. The Spenders. New York: McGraw-Hill Book Company, Inc., 1960.

Festinger, Leon. The Theory of Cognitive Dissonance. Evanston, Illinois: Row-Peterson and Company, 1957.

Foote, Nelson N. "The Autonomy of the Consumer," Consumer Behavior, The Dynamics, Clark, Lincoln H. (ed.). New York: New York University Press, 1955.

Frith, L. E. Testing Advertisements. New York: McGraw-Hill Book Company, First Edition, 1934.

Halbert, Michael H. "A Practical and Proven Measure of Advertising Effectiveness," Marketing Management and Administrative Action, Britt, Steuart Henderson, and Harper W. Boyd, Jr. (eds.). New York: McGraw-Hill Book Company, 1963. 
Herzog, Herta. "Behavioral Concepts for Analyzing the Consumer," The Environment of Marketing Behavior, Holloway, Robert J. and Robert S. Hancock (eds.). New York: John Wiley and Sons, Inc., 1964.

Howard, John A. Marketing Management: Analysis and Planning (rev. ed.). Homewood, Illinois: Richard D. Irwin, Inc., 1963.

Katona, George. The Powerful Consumer. New York: McGrawHill Book Company, 1960.

Klapper, Joseph T. The Effects of Mass Communication. Glencoe, Illinois: The Free Press, 1960.

Lewin, Kurt. "Group Decision and Social Change," Readings in Social Change, Newcomb, T. M., E. L. Hartley, and others. New York: Henry Holt and Co., 1947.

Lucas, Darrell Blaine and Steuart Henderson Britt. Advertising Psychology and Research. New York: McGraw-Hill Book Company, 1950.

Martineau, Pierre. "Motivation in Advertising: A Summary," The Role of Advertising, Sandage, C. H. and Vernon Fryburger (eds.). Homewood, Illinois: Richard D. Irwin, Inc., 1960.

Sandage, C. H. and Vernon Fryburger. Advertising Theory and Practice. Homewood, Illinois: Richard D. Irwin, Inc., Fifth Edition, 1958.

Stigler, George J. The Theory of Price. New York: The MacMillan Company, 1946.

Yates, Frank. Sampling Methods for Censuses and Surveys. New York: Hafner Publishing Company, 1949.

\section{Publications of Agencies and Associations}

American Dairy Association. Public Attitudes and Uses of Dairy

Products. Highlights Study No. 8. Chicago, Illinois: American

Dairy Association, Fall, 1958.

American Dairy Association. Public Attitudes and Uses of Dairy

Products. Highlights Study No. 3. Chicago, Illinois: American

Dairy Association, Fall, 1958.

Boatwright, John W. "Attitude Analysis and Sales Planning," Michigan Business Papers. No. 27. Ann Arbor, Michigan: University of Michigan, 1953.

Brandow, G. E. Interrelationships Among Demands for Farm Products and Implications for Control of Market Supply. Pennsylvania Agricultural Experiment Station Bulletin No. 680. August, 1961.

Clement, Wendell E. and Peter L. Henderson, Consumer Response to Various Levels of Advertising for Fluid Milk. U. S. Depart- 
ment of Agriculture, Marketing Research Report No. 805. Washington: Government Printing Office, October, 1967.

, Peter L. Henderson, and Cleveland P. Eley. The Effect of Different Levels of Promotional Expenditures on Sales of Fluid Milk. U. S. Department of Agriculture, ERS-259. Washington: Government Printing Office, October, 1965.

Frye, Robert E. and Violet Davis Grubbs. Promotion of Farm Products by Agricultural Groups. U. S. Department of Agriculture, Marketing Research Report 380. Washington: Goverment Printing Office, January, 1960.

Havas, Nick, Violet Davis Grubbs, and Hugh M. Smith. Combining Kinds of Retailer Promotions. United States Department of Agriculture, AMS-397, Washington: Government Printing Office, August, 1960.

Hayer, Ralph M. "Advertising Impact Research," Michigan Business Papers, No. 27. Ann Arbor, Michigan: University of Michigan, 1953.

Henderson, Peter L., Sidney E. Brown, and James F. Hind. Special Promotional Programs for Apples: Their Effects on Sales of Apples and Other Fruits. U. S. Department of Agriculture, Marketing Research Report 446. Washington: Government Printing Office, January, 1961.

, James F. Hind, and Sidney Brown. Promotional Programs for Lamb and Their Effects on Sales, U. S. Department of Agriculture, Marketing Research Report No. 522. Washington: Government Printing Office, January, 1962.

and M. Elton Thigpen. Evaluation of a Special Promotional Campaign for Frozen Concentrated Orange Juice. U. S. Department of Agriculture, Marketing Research Report No. 693. Washington: Government Printing Office, February, 1965.

Hensley, Harry C. and Neil H. Borden. Marketing Policies of the California Walnut Growers Association, Farm Credit Administration, Bulletin No. 10. Washington: Government Printing Office, March, 1937.

Hind, James F., Cleveland P. Eley, and Carl R. Twining. Special Promotional Programs for Winter Pears. U. S. Department of Agriculture, Marketing Research Report No. 611. Washington: Government Printing Office, July, 1963.

Hunter, J. Scott, Wendell E. Clement, and Nick Havas. Promotion of Lamb. U. S. Department of Agriculture, Marketing Research Report No. 292. Washington: Government Printing Office, December, 1958.

Lamb and the Consumer. A Report of a research project spon- 
sored by The American Sheep Producers Council, Inc., in cooperation with the United States Department of Agriculture, 1964.

Metz, Joseph F., Jr. Methods of Research in Marketing. Paper No. 5. Ithaca, New York: Dept. of Agr. Econ., Cornell University, July, 1956.

Mitchell, Glen H. Telephone Interviewing. A. E. 279. Wooster, Ohio: Ohio Experiment Station, November, 1957.

Seaver, S. K. and I. W. Hardie. The Economics of Advertising Milk, A Special Case. Research Report 12. Storrs, Connecticut: Agr. Experiment Station, June, 1966.

Twining, Carl R. and Peter L. Henderson. Promotional Activities of Agricultural Groups. United States Department of Agriculture, Marketing Research Report No. 742. Washington: Government Printing Office, December, 1965.

\section{Periodicals}

Axelrod, Joel. "A Validation of Murphy's Law," Journal of Advertising Research, Vol. 7, No. 3, September, 1967.

Banks, Seymour. "The Relationships Between Preference and Purchase of Brands," Journal of Marketing, Vol. 15, No. 2, October, 1950.

Barclay, William D., Richard M. Doub, and Lyron T. McMurtrey. "Recall of TV Commercials by Time and Program Slot," Journal of Advertising Research, Vol. 5, No. 2, June, 1965.

Bayton, James A. "Contributions of Psychology to the Microeconomic Analysis of Consumer Demand for Food," Journal of Farm Economics, Vol. 45, No. 5, December, 1963.

"Motivation, Cognition, Learning-Basic Factors in Consumer Behavior," Journal of Marketing, Vol. 22, No. 3, January, 1958.

Bilkey, Warren J. "A Psychological Approach to Consumer Behavior Analysis," Journal of Marketing, Vol. 18, No. 1, July, 1953.

"The Vector Hypothesis of Consumer Behavior," Journal of Marketing, Vol. 16, No. 2, October, 1951.

Britt, Steuart Henderson. "The Strategy of Consumer Motivation," Journal of Marketing, Vol. 14, April, 1950.

Burk, Marguerite C. "Survey of Interpretations of Consumer Behavior by Social Scientists in the Postwar Period," Journal of Farm Economics, Vol. 49, No. 1, Part 1, February, 1967.

Cahalan, Don. "Measuring Newspaper Readership by Telephone: 
Two Comparisons with Face-to-Face Interviews," Journal of Advertising Research, Vol. 1, No. 2, June, 1961.

Cheskin, Louis and L. B. Ward. "Indirect Approach to Market Reactions," Harvard Business Review, Vol. 26, No. 5, September, 1948.

Crockett, Walter Hobson. "The Effect of Attitude Change of Cognitive Differentiation and Affect Under Conditions of Norm-Presentation with and without Counter Arguments," Dissertation Abstracts, Vol. 13, No. 3, 1953.

Eastlach, J. O., Jr. "Recall of Advertising by Two Telephone Samples," Journal of Advertising Research, Vol. 4, No. 1, March, 1964.

Eldridge, Clarence E. "Advertising Effectiveness-How Can It Be Measured?”, Journal of Marketing, Vol. 22, No. 3, January, 1958.

Ferber, Robert. "Our Changing Consumer Market," Business Horizons, Vol. 1, No. 2, Spring, 1958.

Festinger, Leon. "Behavioral Support for Opinion Change," Public Opinion Quarterly, Vol. 28, No. 3, Fall, 1964.

Freeman, Cyril. "How to Evaluate Advertising's Contribution," Harvard Business Review, Vol. 40, July-August, 1962.

Greene, Jerome D. and J. Steven Stock. "Brand Attitudes as Measures of Advertising Effects," Journal of Advertising Research, Vol. 6, No. 2, June, 1966.

Greer, Paul E. "Bayesian Decision Theory in Advertising," Journal of Advertising Research, Vol. 2, No. 4, December, 1962.

Hafler, David (ed.). Wood Chips, Vol. 1, No. 1, Philadelphia, Pennsylvania: A. J. Wood and Company, December, 1954.

Haskins, Jack B. "Factual Recall as a Measure of Advertising Effectiveness," Journal of Advertising Research, Vol. 4, No. 1, March, 1964.

Hill, Conrad R. "Another Look at Two Instant Coffee Studies," Journal of Advertising Research, Vol. 1, No. 2, December, 1960.

Kerby, Joe Kent. "Semantic Generalization in the Formation of Consumer Attitudes," Journal of Marketing Research, August, 1967.

Kildegaard, Ingrid C. "Telephone Trends," Journal of Advertising Research, Vol. 6, No. 2, June, 1966.

Langhoff, Peter. "Options in Campaign Evaluation," Journal of Advertising Research, Vol. 7, No. 4, December, 1967. 
Liefeld, John Paul. "An Exploratory Study in Theory and Methodology of Consumer Behavior and Market Segmentation," Dissertation Abstracts, Vol. 27, No. 9, 1966.

Marantz, Marcel, "Evaluating Department Store Advertising," Journal of Advertising Research, Vol. 7, No. 1, March, 1967.

Matricon, Claude-Pierre. "A New Index of Advertising Effectiveness," Journal of Advertising Research, Vol. 7, No. 4, December, 1967.

Meissner, Frank. "Sales and Advertising of Lettuce," Journal of Advertising Research, Vol. 1, No. 3, September, 1961.

Palda, Kristian S. "Sales Effects of Advertising: A Review of the Literature," Journal of Advertising Research, Vol. 4, No. 3, September, 1964.

Pilgrim, Francis J. and Joseph M. Kamen. "Patterns of Food Preferences Through Factor Analysis," Journal of Marketing, Vol. 24, No. 2, October, 1959.

Politz, Alfred. "Motivation Research from a Research Viewpoint," The Public Opinion Quarterly, Vol. 20, No. 4, Winter, 1956-57.

Portis, Bernard. "Psychological Concepts for Consumer Research," Journal of Advertising Research, Vol. 6, No. 3, September, 1966.

Tucker, W. T. and John J. Painter. "Personality and Product Use," Journal of Applied Psychology, Vol. 45, No. 5, 1961.

Vinding, Niels, "Awareness, Belief, and Choices of Toothpaste Advertising," Journal of Advertising Research, Vol. 4, No. 1, March, 1964.

Waugh, Frederick V. "Needed Research on the Effectiveness of Farm Products Promotions," Journal of Farm Economics, Vol. 41, No. 2, May, 1959.

"Will the Dismal Science Study the Happy Art?" (Editorial), Journal of Advertising Research, Vol. 7, No. 2, June, 1967.

Winick, Charles. "Anthropology's Contribution to Marketing," Journal of Marketing, Vol. 25, No. 5, July, 1961.

Woods, Walter A. "Psychological Dimensions of Consumer Decision," Journal of Marketing, Vol. 24, No. 3, January, 1960.

Unpublished Materials

Clement, Wendell E. "A Study of the Advertising Process and Its Influence on Consumer Behavior." Unpublished Ph.D. Dissertation, American University, Washington, D. C., April, 1967.

Quackenbush, Gerald. "The American Dairy Association Special 
Milk Promotion Test: Additional Evaluation Including Attitude and Behavior Changes." Talk presented to Board of Directors, American Dairy Association, Denver, September 21, 1965.

Taylor, George A. (then Manager, Dairymen's Cooperative Sales Association) personal letter to author dated November 22, 1960.

\section{ACKNOWLEDGMENTS}

This study is an outgrowth of the author's interest in the marketing problems of dairy farmers. For a number of years, questions concerning the effectiveness of advertising in promoting the sale of unbranded milk have arisen in discussions with farmers, farm organization leaders, and professional scientists.

The author is indebted to the Department of Agricultural Economics and the West Virginia Agricultural Experiment Station for providing the necessary research funds and to the Dairymen's Cooperative Sales Association and the American Dairy Association for providing the funds and arranging for the advertising campaign which made the study possible. Encouragement was given to this study by the late Dr. W. W. Armentrout, as Chairman of the Department of Agricultural Economics, West Virginia University, and his successors, Dr. Homer C. Evans and Dr. Kenneth D. McIntosh. The author is also indebted to Dr. Marguerite C. Burk, of the Agricultural Research Service, United States Department of Agriculture and formerly Professor of Agricultural and Home Economics, University of Minnesota, for constructive criticism during the analysis of the data and preparation of the manuscript. Responsibility for any errors in planning and execution, however, rest solely on the author.

Assistance in the supervision of the interviews in the control city was given by a former colleague, William O. Champney. Statistical counsel was provided by Dr. Robert S. Dunbar, Jr. in the planning and early analytical phases of the study and by Dr. Stanley Wearden and Dr. Donald F. Butcher during the final analyses. Major assistance in statistical tabulation and analysis was given by Mary C. Templeton. 


\section{WEST VIRGINIA \\ BOARD OF REGENTS}

Earle T. Andrews, President, Berkeley Springs

Amos A. Bolen, Vice-President, Huntington

John E. Amos, Secretary, Charleston

Dr. Forrest L. Blair, Walker

David B. Dalzell, Moundsville

Mrs. Elizabeth H. Gilmore, Charleston

Edward H. Greene, Huntington

Albert M. Morgan, Morgantown

Okey L. Patteson, Mount Hope

Daniel B. Taylor, ex officio, Charleston

Dr. Prince B. Woodard, Chancellor, Charleston

\section{WEST VIRGINIA UNIVERSITY \\ ADVISORY BOARD}

Charles C. Wise, Jr., Chairman, Charleston

Paul B. Martin, Vice-Chairman, Martinsburg

Leslie C. Gates, Beckley

Robert E. Mentzer, Weirton

Richard A. Raese, Morgantown

Fred R. Toothman, Huntington

Dr. A. J. Villani, Welch

West Virginia University Agricultural Experiment Station College of Agriculture and Forestry

A. H. VanLandingham, Director Morgantown 